Fundamentals of Physiology. by Ebert Tokay. Pp. 336. New York, The New Home Library. 1944.

The author is an instructor in physiology at Vassar College. Intended primarily for the layman, the book he has written may serve well as a text for a college course in physiology. In simple language and clear style, the book commences with the general principles of physiology and the organization of the body and then proceeds to discuss the various systems, such as the respiratory and digestive, in more detail. Technical ternns, when used, are fairly well defined. A series of 149 original drawings illustrate the text matter. These, for the most part, are helpful but unfortunately some are poorly reproduced.

Vitamins and Hormones, Volume I. Edited by R. S. Harris and K. V. Thimann. Pp. 452. (\$6.50) New York, Academic Press, Inc., 1943.

This book is the first of a series of reference volumes summarizing the current research effort on the chemistry and physiology of vitamins and hormones.

There are ten separate articles on widely separated topics. In view of the highly technical nature of the separate discussions, one must have a broad interest to encompass any considerable portion of any two articles in this book. Therefore this book is obviously intended as a reference work. This intended organization of future volumes has not been made public but one might question the association of subjects in Volume I. For example, an excellent article on the int.mate chemistry of compounds from the adrenal cortex is present in the same volume with a discussion of growth factors for protoza, the significance of the vitamin content of tissues, and the physiology of antipernicious anemia material. Despite this minor criticism this valuable book should be available to all who are do ning fundamental research on the vitamins or hormones. The chapter on physical methods for the identification and assay of vitamins and hormones is especially to be recommended as an excellent presentation and evaluation of current available technics.

Other chapters deal with the chemistry and dietary significance of choline, the appraisal of nutritional states, photoreceptor function of carotenoids and vitamins $\mathrm{A}$, intermediate metabolism of sex hormones, and the chemical and physiological relationship between vitamins and amino acids. Readers will look forward to succeeding volumes of this valuable work. It is to be hoped that the future essayists will follow the example of their predecessors in Volume I and not become ton absorbed in the task of recording facts to point out where knowledge is incomplete.

Textbook of Biochemistry. By Benjamin Harrow, 3rd edition, pp. 536, (\$4.00), Philadelphia and London, W. B. Saunders Co., 1943.

The first edition of this book appeared in 1938. That a third edition should be brought out within five years is indicative of both the rapid advances being made in biochemistry and the popularity of the book. The present edition is one hundred pages longer than the second. To keep future editions within the confines of the present size, and still cover new material, it would be well to sacrifice certain sections. Curtailment or deletion of parts of the book dealing with foods, vitamins and endocrinology would be advisable since these subjects are discussed adequately in texts on nutrition, physiology and endocrinology.

The book is concise and readable. Most of the illustrations are good; a few, however, are disappointing for a textbook of biochemistry. (For example what relation has figure 51 to the text material?) Physical chemistry is perhaps treated at insufficient length but this no doubt is a matter of opinion of what a textbook of biochemistry should cover. To the brief discussion of the nature of trypsin and pepsin, a note should be appended to inform the reader that these enzymes in crystalline form do not behave the same as they do in digestive secretion.

The book will give the medical student nearly all he needs to know for his course in biochemistry and is also an excellent refresher for the doctor. It is recommended for its down-to-earth treatment of the subject.

\title{
Abstracts of Current Literature
}

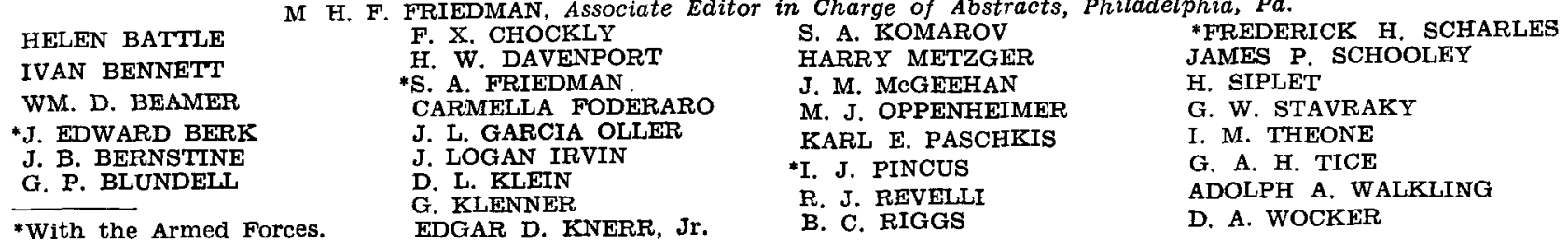

(Microfilm copies of papers may be obtained from Medicofilm Service of the Army Medical Library at 25c for each complete article, not exceeding 25 pages in length-and $10 \mathrm{c}$ for each additional 10 pages or fraction thereof. Prepayment is not requested. Remittances may be made with subsequent orders and in such manner as found most convenient. Address-Medicofilm Service, Army Medical Library, Washington, D. C.)

\section{CLINICAL MEDICINE}

StOMACH

Laws, H. W.: Hernia of the stomach through the right side of the diaphragm. (Canadian Med. Assoc. J., V. 50, P. 62, January 1944.)

Left-sided diaphragmatic herniation of the stomach has been known to result from trauma. However, it has generally been believed that right-sided diaphragmatic hernia is due only to some congenital malformation. The present case would tend to dispel this conception. The patient was a 36 year old army mechanic who presented a history which led to the conclusion 
that his right-sided hernia was traumatic in origin.F. E. St. George.

\section{BowEL}

Daniels, E. I.: Ano-rectal suppurative disease and ano-rectal fistula. (Canad. Med. Assoc. J., V. 50, P. 147, February 1944.)

The successful correction of suppurative affections of the ano-rectal region depends upon a thorough and modern knowledge of the anatomy of the region. The author has been able to correct over 400 acute or chronic peri-rectal suppurative cases without resultant incontinence. The anatomy is described. While the usual organisms found were staph. aureus and B. pyocyaneus, only one of the entire series had a true tuberculous infection. Any two of three factors are necessary for development of peri-ano-rectal suppuration: 1. Liquid or mushy stools lodging in crypts of Morgagni. 2. Presence of rudimentary racemose multilocular glands in the peri-anal or peri-rectal spaces; and 3. Loweed resistance to infection. The frequency and nature of the various types (or situations) of abscesses are discussed. In diagnosis, palpation is best and probing or dye injection into chronic fistulous tracts is to be deprecated. In treatment, immediate drainage is required for the acute abscess, and this is done by the "open de-roofing method", using "saddle anaesthesia". All chronic tracts are completely removed, and all operations are done in one stage. Packing is never used and bowel function is not altered.Wm. D. Beamer.

Pemberton, $J$. de $J$., and Brindley, $G . V .: T u b-$ erculosis of the rectum: report of case. (Proc. Staff Mect. Mayo Clinic, V. 19, P. 46, January 26, 1944.)

Tuberculosis of the rectum is rare. The caseous or ulcerative type is secondary to tuberculosis elsewhere in the body and is commoner than the noncaseous or hyperplastic type which is primary in nature. The hyperplastic lesion usually occurs in the ileocecal valve and cecum; extremely few have been reported occurring in the rectum. The case history of a 41 year old male who had the rectum resected is given; on the basis of microscopic appearance and the exclusion of other possibilities, the diagnosis of primary hyperplastic tuberculosis was made.-I. M. Theone.

Burrows, R.: Studies on intestinal parasites of mental patients. (Am. J. Hygiene, V. 38, P. 293, November 1943.)

Anal swabs were made in 1,383 patients and more than 3000 stool specimens taken from 2,055 patients who were all inmates of the South Carolina State Hospital. The staff members of the mental hospital were also exam ned, as were also the soil, walls, doorknobs, furniture, toilet seats, etc. The incidence of infestation by intestinal parasites was higher in mental cases than in the general state population. The longer the confinement to the mental hospital, the greater was the intensity of the infestation as well as the number of parasitic species. The more severe mental cases were more heavily parasitized and the staff members attending these patients were likewise more parasitized. -F. X. Chockley.

Milligan, E. T. C.: Functional disease of rectum and colon. (Lancet, 245 (6253): P. 29, 1943.)

"Rehabilitation" is discussed. Of 3 methods (the strainless daily-habit rhythm, the response to the consc.ous call, and aperient addiction) only the first gave satisfactory emptying of the bowel and satisfaction of the mind.-Courtesy Biological Abstracts.

\section{PanCREAS}

Kennedy, R. L. J. and Boggenstross, A. H. Fibrocrystic disease of the pancreas. (Proc. Staff Meet. Mayo Clinic, V. 18, P. 487, December 15, 1943.)

Fibrocystic disease of the pancreas in children has many of the features of coeliac disease:-intolerance to fat and carbohydrate, foamy light-colored foul-smelling stools, and failure to gain in weight and height. Unlike cases of coeliac disease, in fibrocystc disease of the pancreas there are also chronic bronchial and pulmonary symptoms which may focus attent:on on the respiratory tract and cause the true nature of the disease to be overlooked. Duodenal contents are without tryptic activity and diet therapy is ineffective. Life expectancy is a matter of months or a few years. Familial tendency is indicated, but not proved. The greatest age attained in all reported eases is 14 years. Etiology is unknown. Congenital obstruction of the pancreatic secretion and retrograde degeneration may be the essental factor. Some believe that a deficiency in vitamin A plays an important role. No therapentic measures have as yet been found. The case histories and pathology reports of 4 patients are given; an addendum on two additional cases is also included.I. M. Theone.

Naffziger, H. C. ANd McCorkle, H. J.: The recognition and management of acute tramma of the pancreas. (Ann. Surg., V. 18, P. 594, October 1943.)

Damage to the pancreas following traumatic injuries to the abdomen are usually masked by other symptoms. Pancreatic damage resulting from trauma has been detected by the authors by determining the levels of blood serum amylase. They believe that values above the normal are due to absorption of amylase from the peritoneal cavity or from interstitial spaces into which pancreatic juice has leaked. When pancreatic damage of this or gin is found, food should be withheld from the patient in order to reduce the secretion of the pancreatic acini to the minimum.-G. Klenner.

Liver AND Gallbladder

Beamer, WM. D. : Biliary drainage by duodenal intubation. (Med. Clin. N. Amer., P. 1659, November 1943.)

A brief history of duodenal intulbation and drainage is given. The technic of passing the tube into the stomach, thence into the duodenum is described. Particular attention is called to necessity of the patient being at perfect ease and understanding the procedure. 
Some simple expedients for encouraging duodenal entry are mentioned. Specimens are obtained best for diagnostic purposes when a proteose solution (Bactoprotone) is used. Magnesium sulfate-peptone solution is successful in about 70 per cent of all drainages. Pavatrine has yielded fairly good results but confuses the specimens. Emptying of the gall bladder is favored by an initial high tonus, and this may be expected when the gall bladder is well filled. However, a highly spastic sphincter of Oddi may interfere with drainage. The bile fractions are noted as to color and clarity first, then examined miscroscopically for diagnostic epithelium, pus, blood, and crystals, as well as bacteria and parasites. Roentgen study should be performed simultaneously with the biliary drainage. Only by duodenal intubation can the process of therapy in biliary tract disease be followed satisfactorily.-Wm. D. Beamer.

Dessau, F. J.: The incidence of gallstones in the higher age groups. (New England J. Med., V. 229, P. 464, 1943.)

In the Long Island Hospital, Boston, there were 3242 post mortems performed during the years 1900 to 1942 inclusive. Of these, 2791 were performed on people over 40 years of age. The incidence of gallstones was found to increase with age. Cholecystitis without gallstones was present in 2.5 per cent of the autopsied patients. Cholecystitis associated with cholelithiasis was seen in 42 per cent of the males and 34 per cent of the females. The incidence of gallstones was greater in the years 1923 to 1942 than 1900 to 1923 . There was a gradual decrease in the sex ratio difference; in later years it has been approximately only twice as prevalent in women than men.-D. A. Wocker.

Schwyzer, A.: White bile. (Minnesota Med., V. 26, P. 955, November 1943.)

The so-called "white bile" seen by the surgeon in cases of bile-duct obstruction usually is not due to infection but to obstruction of bile flow. The "white bile" is not a secretion of the hepatic cells but of the glandular cells of the bile ducts. The white bile actually is not white but colorless and is devoid of bile acids and bile pigments. A colorless secretion from the hepatic cells is found only when the liver is extremely damaged but the ducts are not obstructed. Usually, however, any secretion from the liver cells is colorless. After release of the obstruction normally colored bile should begin to flow within forty-eight hours. Schwyzer discusses nine cases from his experience, excluding hydrops of the gall-bladder-G. Klenner.

\section{ULCER}

Rотне, H.: Incidence of gastric and duodenal ulcers in war. (Deutsch. med. Wochenschr., V. 67, P. 810, 1941.)

Results of 7;488 studies over 3 years, 1937-40, are reported. A considerable periodicity was noted, with a maximum incidence in winter and without marked peaks in spring or fall. The total number of examina- tions increased somewhat during the last 2 (war) years and the percentage of positive findings increased. The frequency of gastric ulcers increased relatively more than that of duodenal ulcers in the last year: the percentage of gastric ulcers, in terms of total ulcers found, was 17.9 for $1937 / 38,11.9$ for $1938 / 39$ and 27.4 for 1939/40.-Courtesy Biological Abstracts.

Fowler, R. H.: External tranma and peptic ulcer. (Indust. Med., V. 12, P. 614, 1943.)

Peptic ulcer as the result of blunt traumatism has an incidence of 0.6 per cent. The question of the traumatic origin of an ulcer has been raised on many occasions in industrial compensation cases. Fowler presents a number of conditions which must be met in order that a peptic ulcer may be recognized as traumatic in origin.-G. Klenner.

\section{SURGERY}

Priestley, J. T., Thompson, L., and Sealy, W. B. : Bacteriologic aspects of gastric content in presence of surgical lesions of the stomach and duodenum. (Proc. Staff Meet. Mayo Clinic, V. 19, P. 1, January 12, 1944.)

While the contents of the normal fasting stomach are usually sterile, bacteria may be present in association with certain gastric lesions. The bacteria normally present in the mouth and oesophagus, and those ingested with food, are destroyed by the acid of the gastric juice. This probably also accounts for the bacteria-free condition of the contents of the duodenum and upper jejunum.

Bacteriologic examination was made of the gastric contents of 41 patients subjected to operation (39 for gastric resection and two for gastroenterostomy). Acidity determinations of the gastric contents were also made. No organisms were found in 24 cases and one or more organisms in 17 . Organisms were rarely recovered from gastric content if the total acidity of juice secreted prior to operation (in response to a Ewald test meal) was more than 40 clinical units. Only 4 out of 22 duodenal ulcer cases showed organisms present in the gastric contents while 6 out of 7 gastric ulcer cases and each of 5 cases of malignant gastric lesion showed organisms.

From the foregoing the authors conclude that every case of malignant gastric lesion or gastric ulcer must be regarded by the surgeon as one where infection already exists. Danger from infection in duodenal ulcer surgery is seldom serious.--I. M. Theone.

\section{EXPERIMENTAL MEDICINE}

Physiology Secretion

Spealman, .C. R.: The volume flow of resting salivary secretion. (Amer. J. Physiol., V. 139, P. 225, 1943.)

The total salivary production was collected by allowing the saliva to drain into a $50 \mathrm{cc}$ beaker over a 5 minute period after the establishment of constant drainage from the mouth. Using the method for determining the resting volume flow of salivary secretion, evidence was obtained that the mean of a 
sufficient number of determinations represented a value which was reproducible and characteristic of the individual. The distribution of the mean of 2 values of a limited number of subjects was skewed. The modal value was about 0.24 cc per minute. The lowest mean of values obtained was $0.08 \mathrm{cc}$ per minute and the highest 0.88 cc per minute--C. R. Spealman.

Physiology Motility

Quigley, J. P., Baron, H. J., Read, M. R., And Brafman, B. L.: Evidence that body irritations or emotions retard gastric evacuation, not by producing pylorospasm but by depressing gastric motility. ( $J$. Clin. Invest., V. 22, P. 839. Nov. 1943.)

Supposed evidence that decreased gastric emptying is due to pylorospasm incident to viscero-visceral or somato-visceral reflexes has accumulated in the literature from three main sources: clinical, roentgenological, and experimental.

Clinical diagnosis of pylorospasm depends largely on support from X-ray studies. But roentgenological studies have usually assumed that the non-visualizing sphincter is either closed or in spasm, which is erroneous. When the sphincter is actually visualized and pylorospasm is distinguished from certain pathological conditions (edema, scar contractures) it has been found that the sphincter is open most of the time, closing intermittently only for brief intervals; and that in many cases of food retention the pylorus is found to be patent.

Numerous studies have gradually established the views that gaster and sphincter behave, not antagonistically as formerly believed, but similarly and as a unit; and that gastric evacuation is dependent largely on gastric peristalsis and not on sphincteric activity. However, past experiments by others in anesthetized animals have led to the conclusion that pylorospasm is induced by visceral and somatic reflexes. The present series of experiments analyzes results obtained from trained unanesthetized dogs, with improved methods of studying sphincteric activity (pyloric diagraph. triple-balloon technique, X-ray).

Nervous states, peripheral nerve stimulation and visceral distention produced a consistent loss of tone and motility of the antrum, sphincter and bulb. Supradiaphragmatic vagotomy will not destroy the inhibiting effects of distention. Increase in sphincteric tone and motility were obtained only by placing 0.4 per cent hydrochloric acid in the duodenal bulb, by gastric distension, and during nausea, retching and vomiting.

These results yield little support to the claim that pylorospasm is produced by emotional states or noxious stimuli.-J. L. Garcia-Oller.

\section{ABSORPTION}

Rammelkamp, C. H. and Helm, J. D. : Studies on the absorption of penicillin from the stomach. (Proc. Soc. Exp. Biol. Med., V. 54, P. 324, December 1944.)

Penicillin is absorbed poorly when administered by mouth. This is due to inactivation by the gastric juice. The acid rather than pepsin is responsible. Saliva. bile and succus entericus do not inactivate the drug. Ab- sorption of penicillin administered by mouth occurred in patients with pernicious anemia.

These experiments show that penicillin should not be given by mouth. The use of enteric coated capsules is not likely to prove effective since the bacteria of the lower intestine may destroy the penicillin tunless the capsule is dissolved in the upper intestine.-M. H. F. Friedman.

\section{Pathology}

Chalkoff, I. L., Entenman, E., Rinehart, J. F., AND ReICHERT, F. L.: Development of cirrhosis in the liver of dogs deprived of both pituitary and thyrod glands. (Proc. Soc. Exper. Biol. Med., V. 54, P. 170. November 1943.)

Dogs deprived of both the pituitary and thyroid glands showed a high blood lipid concentration. Although the diet of such dogs was adequate with respect to caloric value, proteins, salts and vitamins, and was not high in fat, the livers of the dogs showed varying stages of cirrhosis. Fat was found distributed in the liver cells both in small and large droplets. Such a high fat content of the liver (11 to 52 per cent) was not found in dogs subjected to thyroidectomy alone.M. H. F. Friedman.

Brown, Clark E.: Dietary ulcers of the esophagus of the rat. (Amer. J. Path., V. 19, P. 785, 1943.)

Of 17 white rats of the Osborne-Mendel strain between 2 and 3 months of age fed a diet of unpolished Texas rice and cottonseed oil for 6 months or longer, 12 developed hyperkeratosis of the esophageal mucosa and in 8 of these there was definite ulceration, sometimes of the penetrating type. Another group of 16 rats similar in age, sex and weight were fed the same deficient diet for 5 months. Then the diet was supplemented by synthetic vitamins and a salt mixture for one month and the rats were sacrificed. Only 4 showed hyperkeratosis of the esophageal mucosa and there was no ulceration. Thus the lesions appear to be primarily dietary in origin.-Courtesy Biological Abstracts.

Krakower, C., Hoffman, W. A., and Axtmayer, J. H. : Portal-systemic collateral veins in the guinea-pig with schistosomal cirrhosis of the liver, and a discussion of congestive splenomegaly. (Arch. Path., V. 36, P. 39, 1943.)

Previous descriptions of portal-systemic venous anastomoses in laboratory animals were based on injections at maximum pressure of portal vein and/ or inferior vena cava in normal animals, or by the production of portal hypertension through various operative methods, entailing the formation of peritoneal adhesions and new vascular pathways. The anastomoses observed in the intact guinea-pig with cirrhosis of the liver produced by experimental infection with Schistosoma mansoni were described. They fell into 2 groups: (1) The minor anastomoses, viz., those that were periesophageal, those in the falciform ligament, in the hemorrhoidal system, and in the distal portion of the inferior mesenteric vein; nothing, however, resembling esophageal, epigastric or hemorrhoidal varices 
was noted. (2) The major anastomoses, necessitated chiefly by the absence of parietal peritoneal fixation of (luodenum, pancreas and colon (as in rodents), occurred in the porto-caval triangle and the lienopancreatic-mesoduodenal areas and were made up of large vessels arising from the superior and inferior mesenteric and gastro-splenic veins. These emptied into the large systemic veins. Congestion splenomegaly (Banti's type) was not obtained. The failure to produce this condition in laboratory animals under natural or experimental conditions is attributed to the fact that in small laboratory animals with portal obstruction, the smaller volumes of portal blood can be shunted more efficiently and with the maintenance of lower pressure. in the absence of hydrostatic pressure due to gravity, through the few, short, direct and indirect anastomoses, larger blood volume, and greater hydrostatic pressure, congestive splenomegaly can occur more readly.Courtesy Biological Abstracts.

Dragstedt, L. R.: Some physiologic probloms in surgery of the pancreas. (Ann. Surg.. V. 118: 576, October, 1943.)

The author reviews his experiences with various operative procedures upon the pancreas, such as complete removal, occlusion of the ducts, transplantation of the ducts to the exterior, etc. He found that when the pancreas was entirely absent, almost all dogs develop fatty infiltration of the liver. This was found to be counteracted by feeding pancreatic tissue to the dogs. Further study showed that occlusion of the ducts produced fatty livers in 50 per cent of the logs, and that the alpha and beta cells survived in the islets in these animals, but the acnar tissue was destroyed. Alpha cells in the acinar tissue may exceed the number in the islets; beta cells are found only in the islets. It is probable that the alpha cells secrete a hormone (lipocaic) which prevents the deposition of excessive fat in the livers, and when occlusion of the pancreatic ducts is complete, these cells in the acinar tissue are injured while those in the islets are not. Young, and Ham and Haist procluce diabetes by destroying the beta cells by anterior hypoplysis extracts, but the alpha cells are not injured except in two dogs and only in these two is there extensive fat deposition in the liver. While almost all dogs with total pancreatic fistulas developed ulcer of stomach or duodenum, (unless heavily treated with alkali), only a dozen of over 400 dogs with the pancreas removed developed ulcers. Those with ligated pancreatic ducts occupy a middle position.-Wm. D. Beamer.

\section{METABOLISM AND NUTRITION}

Kunstadter, R. H. and Necheles, H.: Studies on the effect and mechanism of amplletamine sulfate on zecight reduction. (Am. J. Med. Sci., V. 205, P. 820, June 1943.)

The experiments were undertaken to determine the possible causes for decrease of appetite and loss of weight of obese children resulting from the administration of amphetamine sulfate. Observations were made of the psychic gastric secretion (acidity and volume) and motility of dogs provided with a double-barreled esophagostomy and a Pavlov pouch. Clinic patients were used also. It was found that the effect of 3 -to 5 mgs of amphetamine sulfate on secretion in Pavlov pouch dogs was variable and transient. Gastric motility was suppressed in these dogs very shortly after administration of the drug and this was found to be true in the human as well. In cases where motility was not arrested altogether it was modified so that typical strong luunger contractions did not occur.

The psychic effects noted in children were increased physical activity, increased mental and physical responses and stronger will power. This increased selfdiscipline was not due to parental policing because when other drugs were given, the children's appetites increased.

The authors conclude that the loss of weight in obese ch:Idren under this treatment may thus be due to the psychic effects of amphetanine plus the depression of hunger and gastric hunger notility.-R. I. Burdick.

White, E. A., Foy, F. R., and Cercedo, L. R.: Essential fatty acid deficioncy in the mouse. (Proc. Soc. Exp. Biol. Med., V. 54, P. 301, Dec. 1943.)

Alb no nice kept on a diet free from fat developed symptoms characteristized by growth retardation, tail and leg necroses, scaly dermatitis, hematuria and kidney lesions. The earliest symptoms of this Burr and Burr syndrome consisted of a dandruff-like clermatitis and appeared on the 30th to 40th day. The development of the symptoms could be prevented by the inclusion of 10 per cent lard in the cliet; similarly the addition of lard to the diet would cure the condition once it had developed--M. H. F. Friednan.

Gomori, G., and Goldner, M. G.: Production of diabctes mellitus in rats with alloxan. (Proc. Soc. Exp. Biol. Mcd., V. 54, P. 287, Dec. 1943.)

Forty rats were given single intraperitoneal injections of alloxan, $200 \mathrm{mg}$ per kilogram body weight, as a 5 per cent solution freshly prepared. The animals were kept in metabolism cages and groups sacrificed at different time intervals. Urine was analyzed for sugar and ketone bodies, blood for sugar, and histolog.cal sections were made of the pancreas, liver and kidneys.

Diabetes mellitus was produced by the alloxan. Polyuria was common. A 30 per cent loss in weight was recorded. The pancreas showed necrosis and complete disappearance of the beta cells. The ducts and the acinar parenchyma showed no changes.-M. H. F. Friedman.

\section{MISCELLANEOUS}

Holding, H. E., McArdee, 13. And Trotter, W. R. : Provention of seasickness by drugs. (Lancet, V. 1, P. 127, January 22, 1944.)

Although seasickness is not so great a problem in the fighting forces as might be supposed, it is desirable to prevent it in all susceptible cases. The best method is by trying various drugs along with dummy tablets in small groups for short voyages in rough seas. Several 
sedative drugs, drugs of the belladonna group, and three proprietary preparations were tested on military persomnel. Of all these drtigs, hyoscine gave the highest percentage of "susceptibles protected." The only undesirable side-effect is clryness of the mouth. It appears that some related drug which will not decrease salivation would be very useful._-Will:am D. Beamer.

Ballon, Oscar Urteaga: Discussion on the pathogenesis of some types of jaundice arith special reference to hemolytic jaundice and to chronic mountain sickness. (An. Fac. Cienc. Mcd., V. 25, P. 89, 1942.)

It is suggested that a type of jaundice exists dependent upon increased threshold for excretion of bilirubin. In hemolytic jaundice, such elevated threshold could be regarded as a pigment from destroyed red cells. A similar compensatory device should be considered as a possibility in explaining the elevated bilirubin level and the polycythen a in chronic mountain sickness.-Courtesy Biological Abstracts.

Howe, H. A. And Bodian, D. : A note on the penetration of poliomyclitis virus from the gastrointestinal tract in the chimpanzee. (J.Ped., V. 21, P. 713, 1942.)

Active v rus from human stools was given to a chimpanzee by stonach tube. (In the th day following first inoculation the animal was delirious--fever $109^{\circ}$ F. Extremit es showed spasms, back stiff. Extensive studies of the bran, medulla, ganglia, spinal cord at different levels from cervical to sacral and intestines showed no pathology except in the celac ganglia and the right sympathetic chain. The latter showed some perivascular cuffing in the thoracic portion and a large area of lymphocytic infiltration in one of the lumbar ganglia. The celiac ganglia contained many areas of infiltration and cuffing adjacent to the efferent nerves. The authors conclude that polionyelit's virus may reach the central nervous system from the gut via the abdominal sympathetics. - Courtesy Biological Abstracts.

Sumachuman, H., Farber, S., and Mabdock, $C$. I..: Pancreate fanction and disease in carly life III. Methods of analying pancreatic cnsyme activity. (Am. J. Dis. Child., 66, 418, October 1943.)

Incubations were carried ont with Ievin tubes or catheters (No. 10 or 12 French depending on the patient's age), and checked for position fluisoscopically. (o)lecton was by gentle aspiration, with inmediate refrigeration of specinnens until analysis. $\mathrm{pH}$ was determined colorimetrically. Lipase was done essentially by the method of Willstatter et al., using a one hour inculbation period. The substrate was olive oil, with albumin and $\mathrm{CaCl}_{2}$ : $n$ a glycine buffer of $\mathrm{pH} 8.9$. Fatty acids were titrated with $\mathrm{KOH}$. Although results varied wiclely in a given patient, and with two preparations of olive oil emulsion, this was not felt to impair the valiclity of the test.

Trypsin was determined in the Ostwald viscosometer with a $3 \%$ phosplate-buffered gelatin substrate, using a one hour incubation period and several determinations to establish the time refuired for a constant propor- tionate decrease in viscosity. Variations in the gelatin are held to account for much of the variability in results. A large drop in activ ty was noted in specinens kept at room temperature for 24 hours. For rapid, approximate determinations, the authors used a gelatin film, noting the concentration of specimen required to liquefy a spot under standard conditions. A third method described was a modification of that of Anderson and Early which determines the maximum dilution of a specimen preventing refrigerator solidification of a standard gelatin solution, whose make-up is given. The first and last methods showed correlation close enough for clinical dependability.

Amylase was determined viscosimetrically essentially according to Davison. The substrate was soluble starch in an acetate buffer at pH 6.8.-B. C. Riggs.

RAFsky, H. A. : Gastrophotography in natural colors in conjunction with gastroscopy. (Am. J. Med. Sci., 206, 618, Nov. 1943.)

The anthor employed the Gastro-Photor camera and took his pictures on Kodachrome film. The camera was placed into the stomach after gastroscopic observation had been performed, and the position of the lesion to be photographed had been determined. This study consists of olservations in forty-one patients with comparison of the findings of both of the above methods as well as by examination of surgical specimens. In $63.4 \%$ of the cases the photographs revealed identical findings with those of the gastroscopist. The author feels that the alded use of the Gastro-Phour or some :milar apparatus is of value in that a permanent record of the findings $w$ ll be avallable, that the findings of different observers may be compared, and that this "enhances the endoscopic examination on one hand, and illustrates its lim tations on the other."--I J. Pincus.

L.ignt, J. S. And Hodes, H. I.. : Studies on epidemic diarrhea of the now-born: isolation of a filtrable agent cansing diarrhea in caloes. (Am. J. Pub. Health, 33, 1451/Dec. 1943.)

Th's report gives the results of studies of 6 separate epiclemics of cliarrhea of the new-born occurring in 3 hospitals in the Baltimore-Washington area during a period of 2 years. Stool cultures were uniformly negatt've for known diarrhea-producing organisms.

In the first two epidemics stools, blood, and nasal washings from a number of the babies were injected by various routes into a variety of the smaller animals, without producing any clefinite disease. In the subsequent 4 epidemics stools of affected babies were given intranasally to. Guernsey calves. A bloody, mucoid diarrhea resulted in the inoculated an mals. Successive calf passages were made. The disease was proluced in a total of 84 calves. The infecting dose was $1 \mathrm{ml}$. of unfiltered material or $8 \mathrm{ml}$. of filtered material. Stools from normal calves did not produce diarrhea. No organism was cultured from the filtered stools.

The authors state that the $r$ eviclence suggests that the agent may be a cause of epidemic diarrhea of the new-born, but admit it is not conclusive.-G. I'. Blundell. 
Rothwell, Thomas K., IJeber, Marshal,L, M.: Pathology among institutionalised psychotics. (J. Nerv. and Ment. Dis., V. 97, P. 397, 1943.)

A study of 420 consecutive cases at post mortem revealed that organic visceral changes were present in 96 per cent and cerebral changes occurred in 30 per cent of 324 brains. The authors failed to demonstrate that these changes were different from the changes seen in non-psychotic subjects. Megacolon was seen in 1.t per cent of the material and confined to schizophrenics.-Courtesy Biological Abstract.

Creseluis, H., Rettger, Gilbert and Leo, F.: Intestinal flora of the guinea pig. (Jour. Bact., V. 46, P, 1. 1943.)

The normal flora appeared to be simple, consisting of a few bacterial types and yeast-like forms. About 80 per cent of the total cultivable flora consisted of lacto-bacillus acidophilus ver. caviae, closely resembling lacto-bacillus of human origin, particularly in its preference for micro-aerophilic and anaerobic conditions, cell and colony form, and nutritional and temperature requirements. It produces smaller and more delicate colonies on appropriate media and appears to be a less hard lactobacillus than the lactobacillus of rat origin. The remaining 20 per cent of the flora was made up mainly of what appeared to be yeasts, soil and air bacteria. With one exception, other commonly occurring intestinal bacteria particularly Escherichia Coli and the entercocci, were absent or scarce. A large anaerobic sarcina form which was highly aerogenic occurred in abundance in some of the guinea pigs and was apparently capable of implanting itself in the intestine. This organism resembles Smit's Sarcina maxima, and should be designated as such, or a variant thereof. Five diets were employed in the investigation and their influence on the flora is presented in a comprehensive chart.Authors.

Calloman, F. T. and Raiziss, G. W.: Effect of oral administration of succinyl sulfapyrasine on bacterial (coliform) flora of the intestine of normal mice. (J. Pham. Exp. Therap., 79, 200, Nov. 1943.)

Two new sulfonamicle derivatives, i.e., succinyl sulfapyrazine and melyl sulfathiazole, were tested for their bactericidal action against the intestinal flora of normal mice. For the sake of comparison the authors also tested st1faguanidine and sulfastuxidine (succinyl sulfathiazole). The method of testing these clrugs followed that previously employed by Marshall, Bratton. White and Litchfield. The results are reported in terms of the effectiveness as a bactericiclal agent and in terms of the toxicity, with blood levels being included. Under the conditions of the experiment succinyl sulfapyrazine appeared highly effective, comparing favorably with sulfaguanicline.-G. P. Blundell.
Bews, D. C. And Choqcette, L. P. E. : A preliminary study of the incidence of intestinal protosoa in the Canadian Armed Forces. (Canadian Med. Assoc. J., 49, 501, Dec. 1943.)

This is a report of the results of a survey of 500 unselected admissions to a military hospital in Quebec. It was shown that during the period from April 26 , 1943 to June 7, 1943, 236 or $47.2 \%$ of these cases harl some form of protozoal cyst. This was interpreted as meaning that at some time, these patients had been exposed to relatively fresh fecal contamination of food or water supply. It was pointed out that the frequency of this infection in a country where sanitation is good, emphasizes the great problem of prevention of dysenteric disorders in the tropics. The zinc sulfate centrifugal flotation method was employed in the exanination of the stool specimens. Problems relating to asynptomatic amebiasis, as well as symptomatic amebiasis, are discussed.-G. P. Blundell.

DUgal, I. P., AND Ross, S.: Effect of partial hepatectomy on the spontaneous activities of the white rat. (Rev. Canadicnne Biol., V. 2, P. 435, Oct. 1943.)

In one group of male rats 75 per cent of the liver was removed while in another group only control dummy operations were performed. In both the control group and the hepatectomized group all spontaneous activity disappeared for some time immediately after the operation. In the control group some activity was present 12 hours after the operation and completely returned to normal 72 hours later. However, in the hepatectonized group, normal degrees of activity did not return before the seventh post-operative day. This difference of 4 clays between the two groups is believed to be of significance. Inasmuch as the liver resumes normal functioning after regeneration by the seventh day, it is believed that a relationship exists between liver function and spontaneous activity. I. M. Theone.

Prunty, F. T. G. And Macoun, S. T. R.: The chloride excretion in steatorrhea: comparison weith the conditions in Addison's discase. (Brit. I. Exp. Path., 24, P. 22, Feb. 1943.)

The patient. age 52 years, complained of attacks of diarrhea for 6 years. At the time of admission he harl cramps nocturnally and swelling of the legs. Asthenia was a prominent symptom. His stools showed 40.8 per cent free fatty acid and 6.1 per cent neutral fat. No acid was present in the fasting gastric contents but an acid response to histamine was obtained. Serum sodium was low. Since pigmentation was also noted, the question of adreno-cortical insufficiency arose. The patient was kept on a high potassium and low sodium diet and still showed satisfactory chloride retention. This did not favor the existence of adreno-cortical insufficiency. The reason for the steatorrhea remained unexplained. - N. N. Underhill. 
INADEQUATE DIETS AND NUTRITIONAL DEFICIENCIES IN THE UNITED STATES

Their Prevalence and Significance The Prevalence of Inadequate Diets As Shown By Surveys

Reprinted with the consent of the National Research Council, 2102 Constitution Avenue, Washington $25, \mathrm{D}$. C.

$\mathbf{E}$ VERY nutritional survey in the past decade has revealed that the consumption of cliets below the recommended standards is widespread in the United States. In 1933 in New York City, 48 percent of the low-income families canvassed had an average daily caloric intake below that estimated to be the minimum requirement; $(1,2)$ 26 percent had diets yielding an energy value by approximately 20 percent or more under that level. In the same year a survey of lowincome families in Baltimore, Cleveland, Detroit, Pittslurgh, and Syracuse slrowed that 27 percent of them had an average daily caloric intake lower than the minimum standard; (2, 3) 18 percent had diets with a caloric value approxinately 20 percent or more below that level. Two-thirds of all the fanilies surveyed consumed diets at or below the minimum standard level for several protective foods. It is to be noted that the minimum level, whether for energy or protective foods, allowed no margin of safety. Consequently, the proportion of families with unsatisfactory diets was much higher than has been represented.

Among families of employed wage-earners and clerical workers in 43 industrial centers in eight major geographical regions, it was found during 1935 and 1936 that the maximum proportion of white familes with good diets in any region was only 21 percent (4). In the region with the poorest showing. no more than 11 percent of the famlies lad good diets. Between these $t w i)$, the percentages in other regions were intermediate. Only 11 percent of the colored families had good diets.

In the Committee's interpretation of the rating of diets and the standards upon which it is based (Table I). anything less than good was considered as not satisfactory:* consequently, the percentage of families with unsatisfactory diets was extremely high. Indeed, by the original rating the proportion of families having diets rated as poort ranged from 40 percent of the white families in one region, as the least. to 64 percent of the colored families in another region, as the greatest.

*According to the system of grading ( $T$ able I) specified in the original paper, ${ }^{+}$fair diets more than met minimum requirements, but were inferior to good diets. Here fair is used in a relative sense. In their interpretation of such a relative scale, persons are apt to attribute a value to a diet which it does not possess on an absolute basis. To many persons fair thay appear to have a certain amount of goodness and to be regarded as satisfactory.
Rather it expresses here a degree of inferiority Especially when a diet falls below a critical level, its relative value of fair is less important than that on an absolute basis it is unsatisfactory. It is doubtful that minimum require ments for any extended period would confer protection against deficiency states. Conse. quently, meeting basic requirements which are inadequate for any prolonged period is no recommendation of goodness. A diet that falls short, even so slightly, and permits delevop. ment of deficiency states, may be relatively fair but absolutely it is unsafe. According to the standards of the study, the Committee regards fair diets as unsatisfactory.

Since these diets failed to meet minimum requirements, a level that will not protect for any protracted period, the Committee would regard them as very poor diets.

About half of the families failed to receive recommended levels of vitamin $B_{1}$; slightly more than half clid not obtain the advised amount of vitamin $C$ and calcium; while

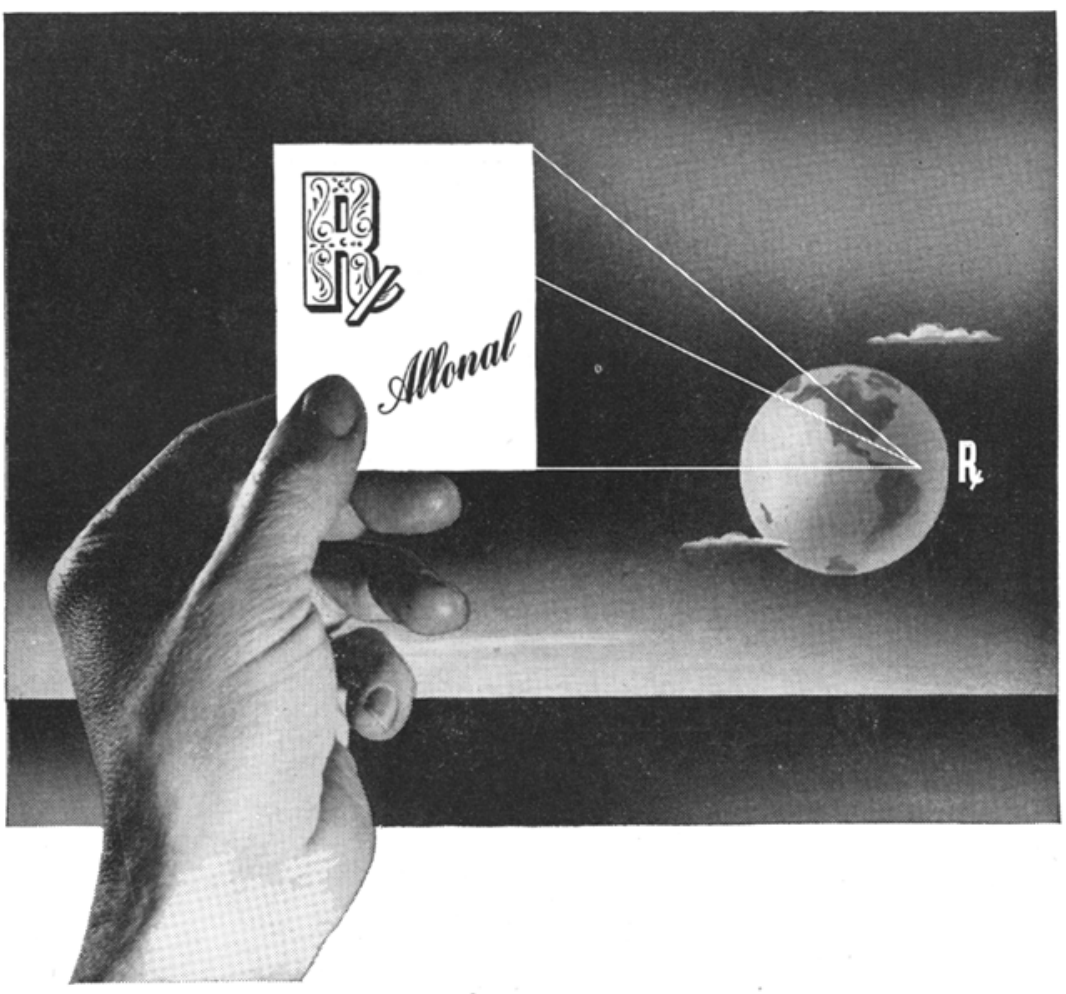

World-wide acceptance of Allonal 'Roche' by the medical profession is a tribute to its efficacy in combating pain and insomnia. Such extensive use is evidence, too, that physicians have found in Allonal their analgesic-hypnotic of choice - one that induces sleep, even in the

ROCHE PRODUCTS ARE NEVER ADVERTISED TO THE LAITY presence of pain, with very little likelihood of unpleasant reactions following its use.

Hoffmann-La Roche, Inc. - Nufley 10 - N. J. 
two-thirds fell short of adequate intake of vitamin $\mathrm{A}$.

Investigations (5) conducted in 66 counties in five broad geographic regions during 1936-37 showed that only 35 percent of white farm operators' families in the North and West and 27 percent in the South had diets meeting recommended allowances (Table I). Thirty-four percent of the families in the North and West and 30 percent in the Sontheast had diets rated as fair. About 10 percent of the families in the North and West and 26 percent in the Southeast were receiving diets poor in one or more nutrients. Since diets rated as fair contained less than 50 percent above the estimated minimum requirements. they should in the Committee's opinion be regarded as poor.* 1)iets rated originally as poror were below the minimum level; therefore. they are actually very poor. If these two infer:or grades of diets be designated as unsatisfactory, it is evident that a substantial proportion of the families were subsisting on a frankly unsatisfactory plane. In the North and West, more than onethird of the diets graded as poor were extrennely low in calcium and vitanin $\mathrm{A}$; and one-fifth were below standard in ascorbic acid. In the Southeast, one-half of the poorest diets were extremely low in vitamins $A$ and $C$ and one-fourth were low in calcium.

Alout one-half of the Negro farm families had diets rated as poor. which in the opinion of the Committee, however, were extremely poor. An additional 28 percent had diet: graded as fair, which practically were poor. Nearly one-fifth of the poorest diets failed to contain even min mum levels of protein and vitamin $B_{1}$; about one-third were short in vitam:n $A$ and riboflavin; and almost one-half in calcium and vitamin C. Contrary to what might be expected, it is clear that even among farm families, engaged in production of food and presumably having ready access to it, the proport on that were improperly fed was extraordinarily high.

During the same years (1936-37) a survey of 140 villages and 20 small cities in five regions stretching across the nation showed that the diets of relatively few families met the specifications of recommended allowances $(6)$. That is a stagger ng statement. Fifty-two percent of the families in the North and West and to percent in the Southeast had diets rated as fair. Twenty-five percent of the families in the North and West and 30 percent in the Southeast had diets rated as poor. Among the Negro fam lies in the Southeast $2+$ percent had diets rated as fair and 63 percent hat diets rated as poor (9). Accorting to a more practical appraisal, the two classes of diets rated as

*Here diets were originally rated (Table I) according to four grades: excellent, good, fair and poor, based as previously upon two stand ards. Diets superior to the recommended stand ard and previously designated good were called excellent. As before, diets inferior to the minimum standard were labeled poor. Diet superior to the minimum standard by less than 50 percent were called fair; by more than 50 but less than 100 percent, good. Thus, the class previously designated as fait was now divided into two classes, good and fair. For reasons already specified, the Committee would regard any diet originally rated less than good as unsatisfactory; and any originally rated good as not above question, since it is on the borderline. In absolute terms, the Committe would regard the fair diet as poor and the poor diet as very poor.

fair and poor were really poor and very poor, respectively. When the percentages of these two categories are comb ned, it is obvious that an appalling proportion of families were rece.ving what might with considerable understatement be called unsatisfactory diets.

In the poorest diets of village families, calcimm, iron, and vitamins $A$ and $C$ were almost never pres-

TABI.E

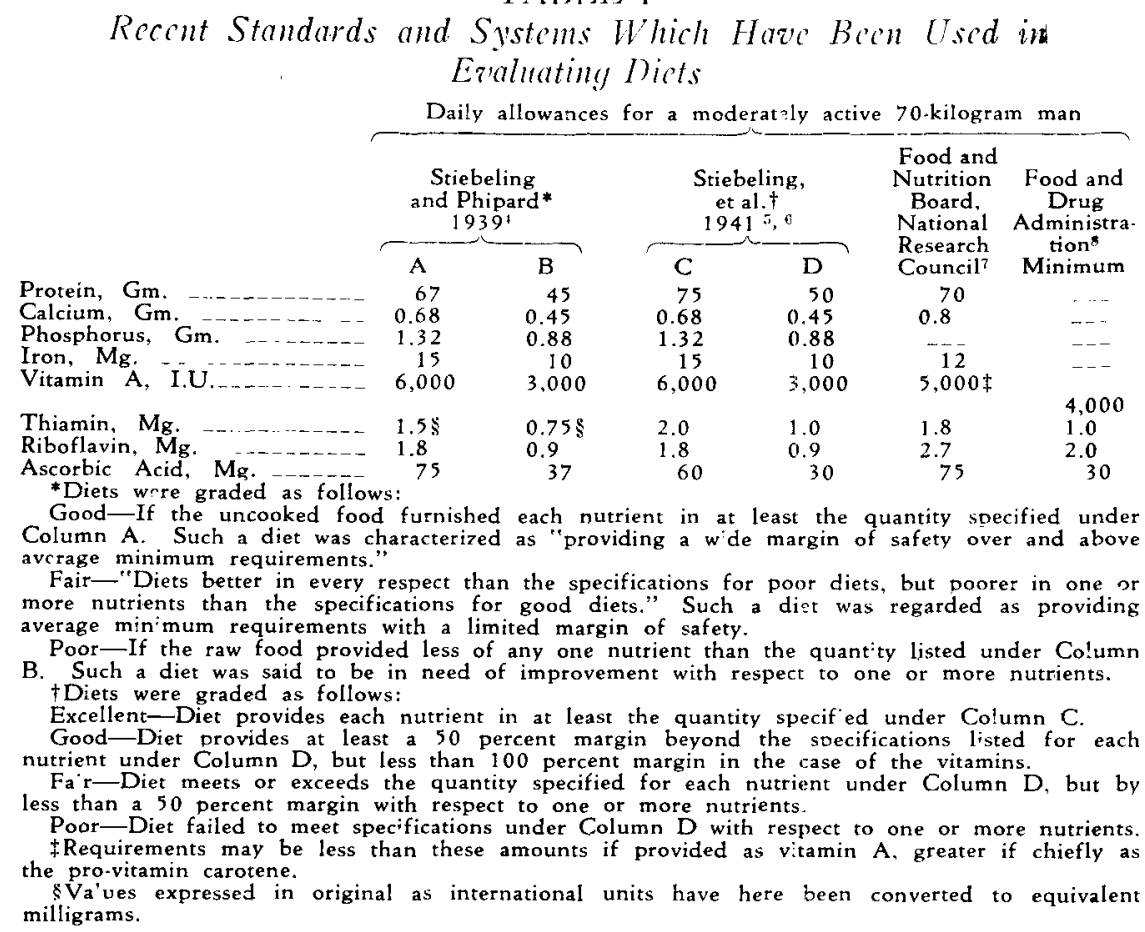
probably also low in niacin, but unfortunately the level of this nutrient was not estimated.

In these studies $(5,6)$ the specifications for an optimum $d$ et used as a standard were formulated prior to the recommended schedule of the Food and Nutrition Board of the National Research Council and were not irlentical with it (Table I). From re-evaluat on (19) of the collected data against the Council's allowances it has since been found that fewer than one-fifth of the famlilies in this country had food supplies in 1936 that met the Conncil's recommendat ons with respect to the seven nutrients studied. About one-fourth of the farm families were in this category. but only about oneseventh of the non-farm families. At least 60 percent of the village and city famil es fell short of the Conncil's allowances with respect to calctum, thiamin, ascorbic acicl, and/or riloflavin, and 30 percent with respect to vitamin $A$. Even on farms, one-fourth fell short of the reconnmended clietary goals in calcium and/or vitamin $A$, and one-half or more with respect to thiam n, riboflavin, and or ascorbic acid. Because neither fool wastes nor nutritive loss in preparation was taken into accomut. it was acknowledged that all the figures on dietary arle. 
quacy as well as those showing the proportion of families meeting the Council's recommendations tend to be optimistic.

Among 538 farm and 299 village families of Vermont visited in 1936, inadequacy in consumption of fruits and vegetables was found to be common; while low intake of protein occurred in families with children (11).

Of 100 submetropolitan urban families in Central and Western Pennsylvania surveyed in 1935-37, it was found (12) that the following percentages had diets containing the several requisite nutrients in amounts less than those recommended by the National Research Council: riboflavin, 59 ; calcium, 58 ; calories, 49; thiamin, 37 ; vitamin A, 33; protein, 29 ; iron, 21 ; and ascorbic acid, 7 .

Inquiry into the diets of pupils in Wilkes Barre, Pennsylvania, in 1937 showed (13) that the following percentages of 748 white children, 1 to 12 years old, were receiving amounts of essentials below the Council's suggested levels : riboflavin, 99 ; calories, 93 ; calcium, 92 ; protein, 81 ; iron, 81 ; thiamin, 74 ; ascorbic acid, 71 ; and vitamin $A$, 67. Of 39 white adolescents, 13 to 20 years old, the percentages were: calories, 100 ; protein, 100 ; calcium, 100 ; thiamin, 100 ; riboflavin, 100 ; iron, 97 ; ascorbic acid, 95 ; and vita$\min \mathrm{A}, 85$. Corresponding percentages for 14 colored children, 1 to 12 years old, were: calories, 100 ; calc um, 100 ; riboflavin, 100 ; protein, 92 ; iron, 92 ; thiamin, 85 ; ascorbic acid, 85; and vitamin A, 54. Dict Surveys Conducted in Years $1938-40$

In a survey in 1938 of families on relief in Washington, D. C., it was found that the average daily intake of 87 percent of the white families was less than 2,800 calories per consumption unit, a standard little if any in excess of actual needs (14). The diets of both white and colored families were extremely low in calcium and only slightly better in iron. Diets as low as these in energy value certainly were deficient in most nutrients.

Diet records of elementary school children in a Maine village-76 in autumn, 1938 and 63 in spring, 1939-showed that only one child in seven attained the minimum standard of one good vitamin $\mathrm{C}$ food daily (15). In the autumn only 17 of the 76 children ate any citrus fruit, the best source of vitamin $\mathrm{C}$, during the week of the record. In the spring, half of the children had some citrus fruit; but only 14 of the 63 had it oftener than once or twice in the week.

To obtain adequate amounts of various essential nutrients, certain types of foods must be eaten in sufficient quantities. Although most of the essential nutrients are distributed in nature in many different foods, some are present in appreciable amounts in only a few types of foods, others only in one type of food. Thus, some essentials to be obtained in sufficient quantities must come from two or three types of food, none of which eaten alone in usual quantities supplies the necessary amount. Other essentials are obtained principally from one type of food. Conversely, a type of food may be the almost exclusive source of a necessary nutrient, or the indispensable source of much of an essential nutrient, or the exclusive source of one and the supplementary source of another nutrient. The several types of food necessary to provide all nutrients form the foundation of the dietary structure. They are essential types of foods because each is the main or indispensable source of one or more requisites.

Unless citrus fruits or tomatoes are included in the diet, it is almost impossible to meet the Council's recommended amounts of vitamin C. Enriched or whole-grain bread or a whole-grain cereal is needed to ensure an adequate supply of vitamin $\mathrm{B}_{1}$. A green or yellow vegetable furnishes a substantial proportion of vitamin $\mathrm{A}$; it also contains some vitamin $\mathrm{B}_{1}$. An adequate quantity of milk provides most of the calcium; it supplies a substantial proportion of riboflavin; it also furnishes a considerable amount of vitamin A supplementing that from vegetables; and it yields some vitamin $B_{1}$. If milk were the sole source of vitamin $A$ in a diet, it would have to be consumed in excessively large quantities to supply the necessary amount of that nutrient. Meat is the main source of niacin; it also provides a considerable supplement of riboflavin; and supplies some vitamin $B_{1}$. If it were the sole source of riboflavin in a diet lacking milk, meat would have to be eaten in exceptionally large amounts. A regular and adequate supply of the principal vitamins and minerals is most readily obtained by consumption of these foods in sufficient amount each day. Otherwise, the diet must be especially planned to furnish all the necessary nutrients.

In its report on Recommended Dietary Allowances (7) the $\mathrm{Na}$ tional Research Council presentel two sample dietary patterns to show the varied ways in which allowances may be met (Table II). List I contains the commonly available types of food. Other combinations of food expertly planned, as in List II, will also cover the allowances.

Of 3,432 women college students in six institutions in the North Central States (16) canvassed during 1936 to 1940 , the following percentages had dietaries containing less than seven servings a week of the respective essential types of foods: whole grain products, 66; citrus fruits, 57 ; green and yellow vegetables, 40; milk, 29; and meat, 14.

Among 19 rural families in Lancaster County, Penna., in 19381940 , it was found (17) that the following percentages of 42 white children, 1 to 12 years old, were eating less than the amounts of the several respective constituents advised by the Board: riboflavin, 81 ; calcium, 64 ; calories, 36 ; thiamin, 36 ; vitamin A, 33; ascorbic acid, 24 ; protein, 21 ; and iron, 17 . For 20 white adolescents, 13 to 20 years old, the corresponding percentages were: riboflavin, 90 ; calcium, 70 ; vitamin A, 45 ; thiam:n, 45 ; calories, 30 ; ascorbic acid, 30; protein, 20; and iron, 20. For 38 white adults the percentages were: riboflavin, 97 ; calories, 87; thiamin, 84 ; vitamin A, 37 ; calcium, 24 ; iron, 10 ; protein, 8; and ascorbic acid, 5.

In a survey during 1939-40 of over 2,000 high school pupils of low-income families in New York City, 74 percent of the pupils had a daily caloric intake below their in- 
dividually calculated energy needs; 21 percent had less than two-thirds of their computed caloric requirements; (18) 44 percent, 64, and 72 percent had less than the Council's recommended daily allowances of protein, iron, and calcium, respectively ; 5,17 (29 percent of the girls), and 28 percent had less than two-thirds of the approved amounts of these respective nutrients. come families. But even among the group from the high-income families, the percentage of pupils with diets that failed to meet accepted standards of adequacy was appreciable.

A survey of dietary records of 1,082 Farm Security Administration families in Louisiana (20) during 1939 and 1940 showed less than 1 percent which could be classified TABLE 2

Sample Dictary Patterns, Prepared by Food and Nutrition Board, National Research Council (7), to Show Ways in Which Allowances May Be Met

LIST I

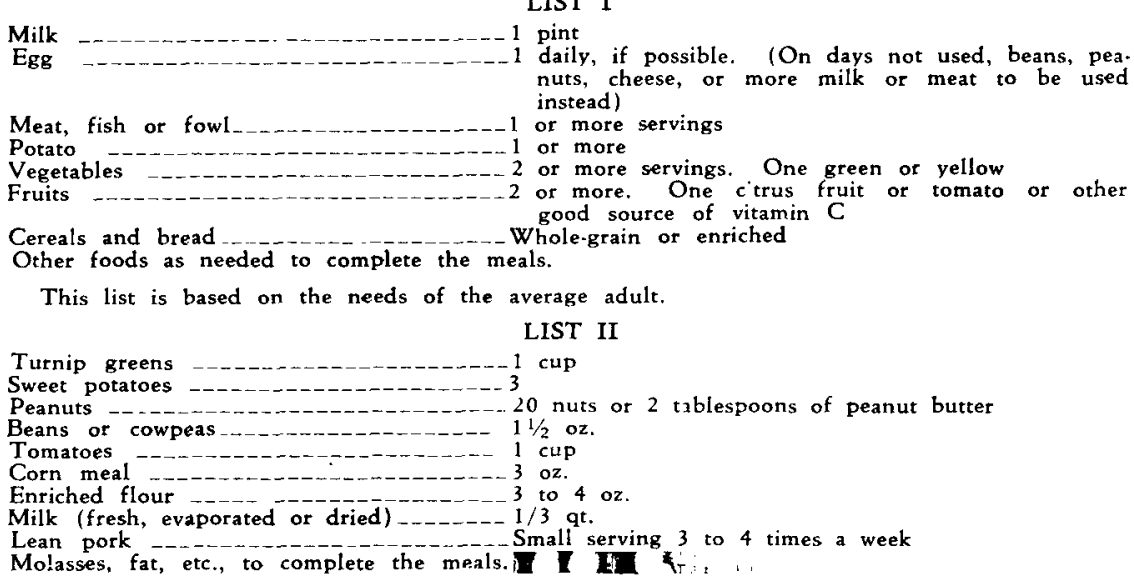

The percentages of pupils having less than the standard daily amounts of the several vitamins were: 65 for vitamin $A, 53$ for vitamin $B_{1}, 70$ for riboflavin, and 58 for vitamin $C$. The percentages with a daily intake of less than two-thirds of the recommended amotnts of these essentials were: 38 for vitamin A, 14 for vitamin B, 25 for riboflavin, and 29 for vitamin C. It should be noted that a daily intake of essential nutrients less than two-thirds of the advocated allowances probably does not meet even min:mum requirements which are not regarded as safe levels.

In contrast, (19) among 293 private school pupils the following percentages had less than the recommended levels of the several essentials: calories, 68 ; calcium, 61 ; iron, 36; riboflavin, 36 ; vitamin $\mathrm{A}$. 35 ; protein, 26; ascorbic acid, 20 ; and thiamin, 18 , respectively. It will be noted that for every essential the percentage of pup ls receiving a substandard amount was less, in most instances much less, in this group from high-income families than in the preceding group from low-in- as good, while 52 percent were fair and 47 percent were poor. Of 573 white families, 1 percent had diets classed as good; 69 percent as fair : 30 percent as poor. Among 509 colored families, none had good diets; 32 percent, fair ; and 68 percent, poor. By using a modification of the pattern established by the National Research Council, a score card was developed for evaluating the adequacy of the diets. A diet was rated good, fair, or poor, depending on the number of times each of the types of essential foods was served during the week. A poor diet was distinctly deficient in one or more of the food factors necessary for optimum health. It was stated that diets classed as fair might be defined as borderline diets. An active individual eating such a diet would not receive enough of the various essential substances to meet adequately his requirement. It is notable that citrus fruits and tomatoes were served least frequently.

Among 225 private patients in the upper-income levels, (21) surveyed in Philadelphia in 1940, the following percentages had diets con- taining less than the Board's recommended allowances for respective nutrients: riboflavin, 77 ; thiamin, 76 ; calories, 74 ; calcium, 46 ; iron, 40 ; protein, 37 ; vitamin A, 26; ascorbic acid, 13. Seven percent of the patients consumed less than the Board's prescribed amounts of all eight factors. The following percentages of the patients had less than 50 percent of the Council's recommended levels of the various constituents: riboflavin, 26; thiamin, 13 ; calcium, 13 ; calories, 5 ; vitamin $A, 5$; ascorbic acid, 4 . In the surveyed group were nine physicians whose diets were as bad as those of the other patients.

Evidence from Dietary Surveys During Past Three Years

From January, 1939 to August, 1941 the dietary habits of 7,363 children and adolescents from 3,922 families in Chicago were surveyed. (22) They represented different national and racial groups and a wide distribution of economic and social conditions in the city. Seventy-six percent were white; 19 percent, Negro; 5 percent, Mexican.

The diet patterns of 72 percent of the children failed to meet a standard lower than that recommended by the National Research Council. Ninety-three percent of the Mexican children, 89 percent of the $\mathrm{Ne}$ gro, and 67 percent of the white were eating diets inferior to even the low standard.

Dietary inadequacies were least often noted in the protein foods and most often in fruits and vegetables. Regardless of which of several $\mathrm{cri}^{-}$ teria was adopted for determining adequacy, a large proportion of the diets fell below the standard in the latter foods. The percentage of children with dets that included less than the low requirements of the different food groups were: for meat, fish, and eggs, 15 ; for milk, 37 ; for fruits and vegetables, including potatoes, 65. Compared with the National Research Council's recommendations, the diets of 73 percent of the white children were below the allowances for fruits and vegetables, and in the poorest areas 98 percent were below this standard (Table 3).

Analysis of records on 110 rural 
adults in Chatham County, North Carolina, surveyed in 1940-41, revealed a $h: g h$ prevalence of unsatisfactory diets. $(23,24)$ Almost all persons received less than the reconmencled daily amounts of the several nutrients: thiamin, 99 ; riboflavin, 97; vitamin $\mathrm{C}$ and calcium. 84 ; prote $n, 83$; iron, 82 ; and vitamin $A, 70$ percent, respectively. Many ate less than half the recommended dietary allowances of the various essentials, as shown by the following percentages: vitamin $\mathrm{C}$. 72 ; riboflavin, 71 ; calcium, 34 ; vitamin A, 27 ; protein, 10 ; and iron, 8 . A considerable proportion of the persons obtained less than onequarter of the standard daily amounts of the nutrients: vitamin C, 45 ; riboflavin, 23 ; thiamin, 17 ; vitamin $\mathrm{A}, 9$; calcium, 4 ; and protein, 1 percent of the subjects, respectively.

\section{TABILE 3}

Percentage of White Children from Relief Families and Non-Relief Families in Different Types of Community Areas in Chicago, Who Consumed Amounts of Protective Foods Below the National Research Council's Recommended Allowances

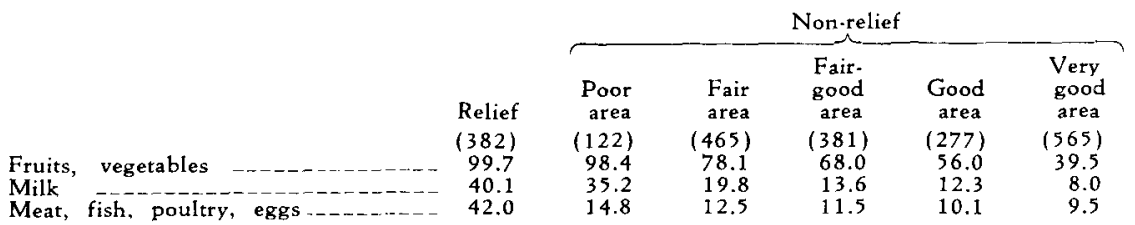

From a study of families, both white and colored, in a rural community in middle Tennessee in 1941, diet records were obtained on 1,161 persons. $(25,27)$ Of 206 white infants and children from ages 1 to 12 years, the following percentages were receiving less than the recommended daily amounts of the several nutrients: thiamin, 79; calcium, 77 ; iron, 70 ; calories, 69; ascorbic acid, 67 ; protein, 61 ; riboflavin. 55; and vitamin A, 45. For 115 colored infants and children in the same age group, the percentages receiving daily amounts of the essentals under the approved level were: calcium, 99 ; calories, 95 ; thiannin, 93; riboflavin, 91 ; protein, 87; iron, 83; ascorbic acid, 70; and vitanin $\mathrm{A}, 51$. The percentages of white infants and children eating less than half the advised daily allowances of the various essentials were: calcium, 39; ascorbic acid, 28 ; thiamin, 23 ; riboflavin, 21 ; vit- amin A, 18; calories, 12 ; protein, 12 ; and iron, 9. Much greater were the percentages of colored infants and children receiving less than half the recommended daily levels, as shown by the following figures: calcium, 70 ; riboflavin, 52 ; thiamin, 47 ; calories, 45 ; protein, 35 ; ascorbic acid, 34; vitamin $A, 34$; and iron, 24.

Of 113 white adolescents from ages 13 to 20 , the following percentages were not receiving the suggested daily amounts of the various nutrients : thiamin, 93 ; calories, 89 ; calcium, 87 ; riboflavin, 85 ; iron, 84 ; protein, 78; ascorbic acid, 68; proportions of 76 colored adolescents in the same age group were failing to obtain the advocated daily levels of the several constituents: calories, 100; riboflavin, 97 ; thiamin, 96; protein, 94 ; calcium, 93 ;

iron, 89 ; ascorbic acid, 73 ; and vitamin A, 59 percent, respectively. Receiving less than half the recommended daily allowances of the various essentials were the following percentages of white adolescents: calcium, 43 ; riboflavin, 41 ; thiamin, 29; ascorbic acid, 29; vitamin $A$. 19 ; iron, 16 ; protein, 13 : and calories, 11. The percentages of colored adolescents eating less than half the standard daily allowances of the respective nutrients were: riboflavin, 62 ; thiamin, 55 ; calcium, 45: ascorbic acid, 42 ; calories, 42 ; vtamin A, 37; protein, 33; and iron, 32.

Of 457 white adults 21 or nore years old, the following percentages were not eating the recommended daily amounts of the respective constituents: thiamin, 94; riboflavin, 91: calories, 82 ; calcium. 61 ; iron, 59; ascorbic acid, 52; protein, 51; and vitamin A, 45. For 194 colored adt1lts, the percentages receiving less and vitamin $\mathrm{A}, 60$. The following than the advised daily levels of the nutrients were: riboflavin, 99 ; thiamin, 98; calories, 95 ; calcium, 77 ; protein, 74; iron, 69; ascorbic acid, 62 ; and vitamin A, 48. Not a few of the white adults were eating less than half the approved daily amounts of the various nutrients, as shown by the following percentages of the persons: riboflavin, 50 ; thiamin, 31 ; calcium, 23 ; ascorbic acid, 21 ; vitamin $A, 15$; calories, 12 : protein, 7 ; and iron, 7. Even greater percentages of colored adults were receiving less than half the recommended daily levels: riboflavin, 77 ; thiamin, 65 ; calories, 40 ; calcium, 40; ascorbic acid, 35 ; vitamin A, 32 ; protein, 18; and iron, 17.

Among children of Newport, Maine, in 1940 and 59 University of Maine freshman girls in 1941, the percentages eating the respective essential kinds of foods in amounts below the standards for a good diet $(28,29)$ are shown in Table 4.

A dietary survey of 1,169 school children in Worcester County. Maryland, (30) in the winter of 1941 revealed that the following percentages were not receiving satisfactory amounts of the various types of food: vegetables other than potato, 81 ; fruit, 80 ; cereal or whole grain, 59; two or more cups of milk a day, 59. In contrast, only 3 percent of the children dicl not obtain sufficient meat.

Only 8 percent of the children had a diet adequate in all five factor's studied. Twenty-three percent were totally deficient in one factor; 35 percent in two; 27 percent in three; and 8 percent in four.

In a study of 780 families of Home Demonstration Club members in twenty-seven parishes in Louisiana (31) in March, 1942, 41 percent had diets scored good; 51 percent, fair; 8 percent, poor. The diets were evaluated by comparing the frequency with which the several types of protective foods were served with the schedule formulated by the National Research Council. In such scoring, it was stated, a poor diet was distinctly deficient in one or more of the food factors necessary for optimum health; while a fair diet did not provide enough of the various food 
factors to meet adequately the requirements. The percentages of families eating less than the recommended amounts of each of the var-
Council's recommendations. Here again the conventional designations given to the four ratings express relative gradations: hence, the rat-

TABLE 4

Percentages of Children of Newport. Maine, and of Freshman Girls of University of Maine Eating Less Than Recommended Amounts of Essential Foods

\begin{tabular}{|c|c|c|c|c|c|c|}
\hline Subjects & $\begin{array}{l}\text { Leafy, } \\
\text { green, and } \\
\text { yellow } \\
\text { vegetables }\end{array}$ & $\begin{array}{l}\text { Citrus } \\
\text { fruts } \\
\text { and } \\
\text { tomatoes }\end{array}$ & $\begin{array}{l}\text { Other } \\
\text { fruits } \\
\text { and } \\
\text { vegetables }\end{array}$ & Milk & $\begin{array}{l}\text { Whole } \\
\text { grain } \\
\text { cereal } \\
\text { and } \\
\text { bread }\end{array}$ & $\begin{array}{l}\text { Meat, } \\
\text { fish, } \\
\text { and } \\
\text { poultry }\end{array}$ \\
\hline Newport childten & $\ldots$ & 80 & 71 & 71 & 62 & 35 \\
\hline College freshman & girls___ 44 & 19 & 22 & 39 & 69 & 0 \\
\hline
\end{tabular}

ious types of essential foods are shown in Table 5.

The eating habits of 6,708 grade and high school students-5,255 white, 1,453 colored-in Louis:ana (32) in 1942 were evaluated as in the preceding study by the dietary pattern recommended by the $\mathrm{Na}$ tional Research Council. Only 11 percent of the white and 3 percent of the Negro children received a diet adequate in all essential food

ing of fair, and possibly good should not be construed as satisfactory. Accordingly, at least 73 percent of the families had unsatisfactory diets.

In 1941-42, the diets of 1,080 workers in the Lockheed Aircraft Corporation at Burbank, California, were analyzed for their content of both protective and essential nutrients. (34) Unless expertly planned for special purposes the diet should

TABLE 5

Percentages of Families of Home Demonstration Club Members and Grade School and High School Students in Louisiana, Eating Less Than Recommended Amounts of Essential Foods

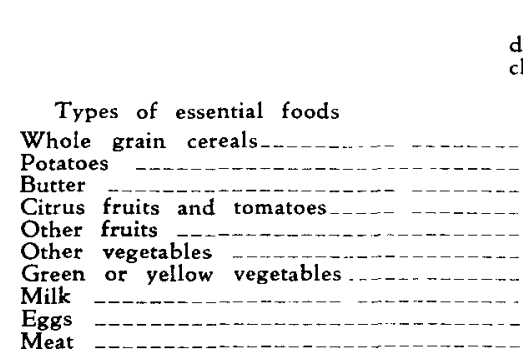

Home
demonstration
club members'
families
$(31)$
$-\quad 86$
$-\quad 54$
$-\quad 53$
$-\quad 45$
$-\quad 41$
$-\quad 34$
$-\quad 28$
$-\quad 20$

$\overbrace{\text { White }}^{\begin{array}{c}\text { Grade school and high } \\ \text { school students (32) }\end{array}} \begin{array}{cc}\text { Colored } \\ 92 & 95 \\ 84 & 92 \\ 66 & 95 \\ 75 & 91 \\ 68 & 83 \\ 76 & 86 \\ 51 & 79 \\ 56 & 91 \\ 77 & 84 \\ 16 & 31\end{array}$

lactors. The diets were fair (borderline) among 60 percent of the white and 35 percent of the Negro students; poor, definitely deficient, in one or more essential nutrients among 29 percent of the white and 62 percent of the Negro children. Diets scored as fair or poor were not regarded as satisfactory. In Table 5 are shown the percentages of students eating less than the recommended anrounts of each of the various types of essential foods.

From a survey of 315 colored families in the Harlem district of New York City (33) in 1942 were reported the following percentages on ratings for food habits : excellent, 8; good, 19; fair, 34 ; and poor, 39. The four ratings were based on the extent to which their food met in kind, amount, and frequency the regularly contain certain types of foods in adequate amounts; otherwise it is almost certain not to provide recommended amounts of the various essentials. These criteria were applied to the data from the dietary survey of the I.ockheed Aircraft workers. Only 36 percent of the men had seven or more servings of citrus fruits or tomatoes during a week. It is surprising that 23 percent had no citrus fruit during a week. About 20 percent had four or more slices a clay of whole wheat, rye, or dark bread. Only 7 percent ate a whole grain cereal every day; slightly over 50 percent used no whole grain breakfast cereal in a week. Only 11 percent of the men ate regularly vegetables containing vitamin A. Twenty-four percent had them less than three times a week. Sixty-three percent reported an average daily consumption of milk less than the accepted standard; 37 percent had an average of less than one-half the recommended amount; 11 percent did not drink milk. Eighty percent of the men ate meat with recommended frequency; an additional 15 percent had nearly the recommended frequency.

The frequency of diets equal to or slightly below the recommended amounts for these types of food and therefore receiving a satisfactory rating for them was as follow': vegetables, 21 ; citrus fruits or tomatoes, 36 ; milk, 51 ; and lean meat, 95 percent, respectively. Unsatisfactory ratings for amounts of specific foods were given to the following percentages of the diets: vegetables, 56 ; citrus fruits or tomatoes, 49; milk, 33 ; and meat, 1.

It is evident that a large proportion of the diets were low in their content of citrus fruits or tomatoes, vegretables, and milk; hence, they would be unsatisfactory in their content of vitamin A, ascorbic acid, riboflavin a nd calcium. Indeed, among the foods eaten in less than recommended amounts vegetables and citrus fruits were outstanding. Only 2 percent of the men had diets which approximated the recommended dietary pattern. While 11 percent of the men reported marginal diets, 87 percent had diets which were unsatisfactory for one or more food types.

One-fourth to one-third of the men probably had insufficient calories in the two-clay period for which the quantitative diet was reported.

For the various nutrients, there was a great difference in the percentage of diets which met the recommended allowances, as shown from study of two-day diets. The allowance for various essentials was met by the following percentages of diets: protein, 85 ; iron, 78 ; niacin, 70 ; vitamin A, 58; thiamin, 54; calcium, 52 ; ascorbic acid, 33 ; and riboflavin, 29. Conversely, diets were deficient by more than onethird of the allowance in the following descending order of frequency for specific nutrients: ascorbic acid, 46 ; riboflavin, 43 ; calcium, 
25 ; vitamin $A, 15$; thiamin, 14 ; niacin, 7 ; and iron, 4 percent.

"It was reported that "only 8 percent of the men had obtained a diet which furnished all nutrients in amounts equal to or greater than the allowances; and not quite 10 percent had diets which furnished 80 to 99 percent of the recommended allowances. Thus, 17 percent of the men had moderately good or excellent diets. The other 83 per-

TABLE 6

Percentages of Persons in the United States, I) stributed According to Geographical Sections, Who Were Found to Not Eat Protectize Foods

\begin{tabular}{|c|c|c|c|c|c|}
\hline Types of essential foods & $\begin{array}{c}\text { New England } \\
\text { and } \\
\text { Middle } \\
\text { Atlantic }\end{array}$ & $\begin{array}{c}\text { East } \\
\text { Central }\end{array}$ & $\begin{array}{c}\text { West } \\
\text { Central }\end{array}$ & South & $\begin{array}{c}\text { Far } \\
\text { West }\end{array}$ \\
\hline $\begin{array}{l}\text { Citrus fruits, tomatoes or greens } \\
\text { Dairy products - vegetables } \\
\text { Leafy and yellow veget } \\
\text { Other vegetables or fruits } \\
\text { Meat, fish, and poultry } \\
\text { Whole grain or enriched products }\end{array}$ & $\begin{array}{r}46 \\
43 \\
28 \\
8 \\
9 \\
3\end{array}$ & $\begin{array}{r}41 \\
31 \\
26 \\
8 \\
12 \\
4\end{array}$ & $\begin{array}{r}43 \\
31 \\
25 \\
5 \\
12 \\
2\end{array}$ & $\begin{array}{r}53 \\
31 \\
21 \\
12 \\
14 \\
3\end{array}$ & $\begin{array}{r}41 \\
28 \\
24 \\
7 \\
14 \\
3\end{array}$ \\
\hline
\end{tabular}

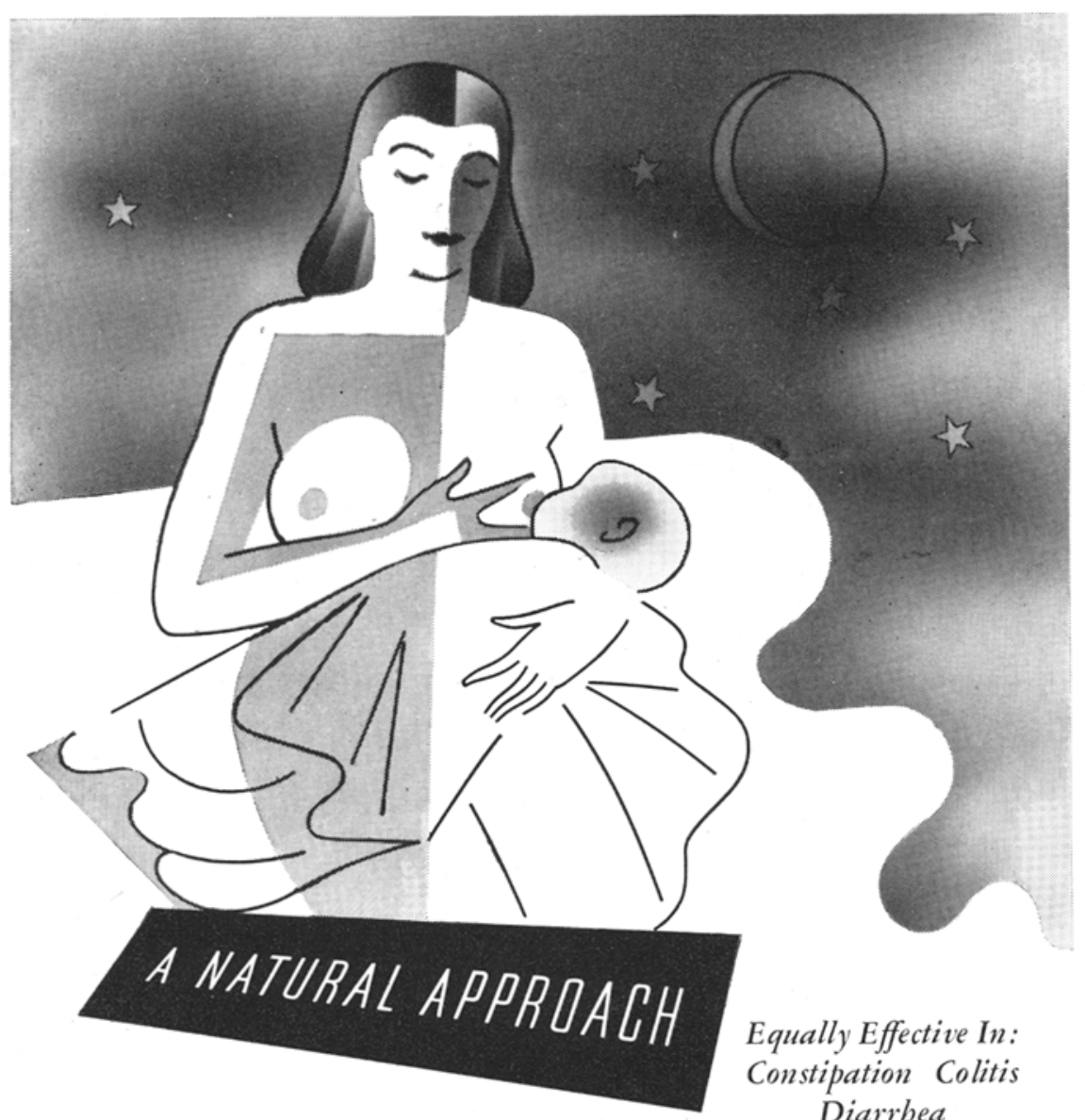

2y ZymenoL ... is a natural approach to the two basic problems of Gastro-Intestinal Dysfunction:

Assures Normal Intestinal Content

through Brewers Yeast Enzymatic Action.*

Restores Normal Intestinal Motility

with Complete Natural Vitamin B Complex.*

This two fold natural therapy restores normal bowel function without catharsis, artificial bulkage or large doses of mineral oil. Cannot affect vitamin absorption, avoids leakage.

Teaspoon Dosage Economical Sugar Free

II'rite For liREE Clinical Size

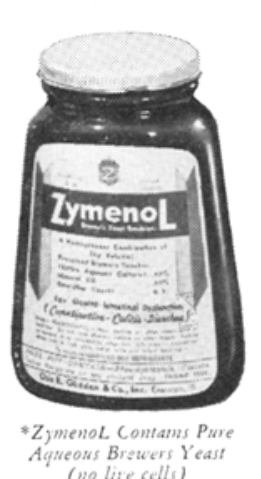

OTIS E. GLIDOEN CO. INC. EYANSTON ILLINOIS

cent of the men needed some improvement in thiir diets. Thirty percent of all diets had less than the two-thirds of the allowance for only one nutrient." When the diet was low in only one nutrient, the specific nutrient involved was ascorbic acid in nearly two-thirds and riboflavin in slightly over one-fifth of such diets. In diets below standard in several nutrients, ascorbic acid was low in nearly two-thirds; riboflavin in 84 percent.

The percentages of 562 white children, 1 to 12 years old, in Phil. adelphia with diets containing less than the advocated levels of the several constituents were found (32) in 1941-42 to be: niac:n, 97 ; calories, 90 ; calcium, 71 ; thiamin, 60 ; protein, 58; iron, 53 ; riboflavin, 53 , ascorbic acid, 52; and vitamin $A$, 42. Similarly, the percentages of 38 white adolescents, 13-20 years old, were: calcium, 100; calories, 93; niacin, 86; protein, 71 ; iron, 71; vitamin $A, 71$; ascorbic acid, 71 ; thiamin, 64; and riboflavin, 64, respectively.

Upon inquiry into the diets of 56 white persons, 15 years or older, in Wayne County, No. Carolina, in the summer of $1942,(24)$ it was found that most of the individuals had less than the approved daily quanta of the several essential substances: namely, riboflavin, 100 ; ascorbic acid, 93; thiamin, 91 ; calcium, 86 : iron, 66; vitamin A, 62; and protein, 55 percent of the persons, respectively. Receiving less than half the advocated daily amounts of the various nutrients were the following percentages of persons: riboflavin, 79; ascorbic acid, 77; thiamin, 43; vitamin A, 27 ; calcium, 25 ; iron, 5 ; and protein, 2.

Of 39 colored persons, the following percentages took less than the advised daily moiet:es of the several nutrients: riboflavin, 97 ; ascorbic acid, 92 ; thiamin, 90 ; calcium, 82; iron, 79; vitamin A, 72; and protein. 59. Very large percentages of them ate less than half the recommended daily allowances of the various essentials: riboflavin, 82 ; ascorbic acid, 69; thiamin, 46 ; vitamin A, 44; calcium, 38; iron, 18; and protein, 10.

A nation-wide canvass in February, 1943, in which one-day diet 
records were obtained from selective samplings of the population in each of the forty-eight states, showed

that the following percentages of persons had none of the respective protective foods: (36) citrus fruits.

\section{TABLE 7}

Percentages of Persons Whose Diets Contaned Less Than Seven Servings AWeek of the Respective Essential Types of Foods

\begin{tabular}{|c|c|c|c|c|}
\hline & $\begin{array}{l}\text { North } \\
\text { Central } \\
\text { States, } \\
\text { Women } \\
\text { College } \\
\text { students } \\
1936-40\end{array}$ & $\begin{array}{c}\text { Newport, } \\
\text { Maine, } \\
\text { children } \\
1940\end{array}$ & $\begin{array}{c}\text { Maine } \\
\text { University } \\
\text { Freshmen } \\
\text { (girls) } \\
1941\end{array}$ & $\begin{array}{c}\text { Burbank, } \\
\text { California, } \\
\text { aircraft } \\
\text { workers } \\
1941.42\end{array}$ \\
\hline Types of essential foods & $(16)$ & $(28)$ & (29) & $(34)$ \\
\hline $\begin{array}{l}\text { Citrus fruits or tomatoes } \\
\text { Dairy products } \\
\text { Leafy and yellow vegetables. } \\
\text { Other vegetables } \\
\text { Meat } \\
\text { Whole grain products }\end{array}$ & $\begin{array}{r}57 \\
29 \\
40 \\
-\quad \overline{14} \\
66\end{array}$ & $\begin{array}{l}80 \\
71 \\
93 \\
71 \\
35 \\
62\end{array}$ & $\begin{array}{r}19 \\
39 \\
44 \\
22 \\
0 \\
69\end{array}$ & $\begin{array}{r}49 \\
33 \\
56 \\
- \\
-\end{array}$ \\
\hline
\end{tabular}
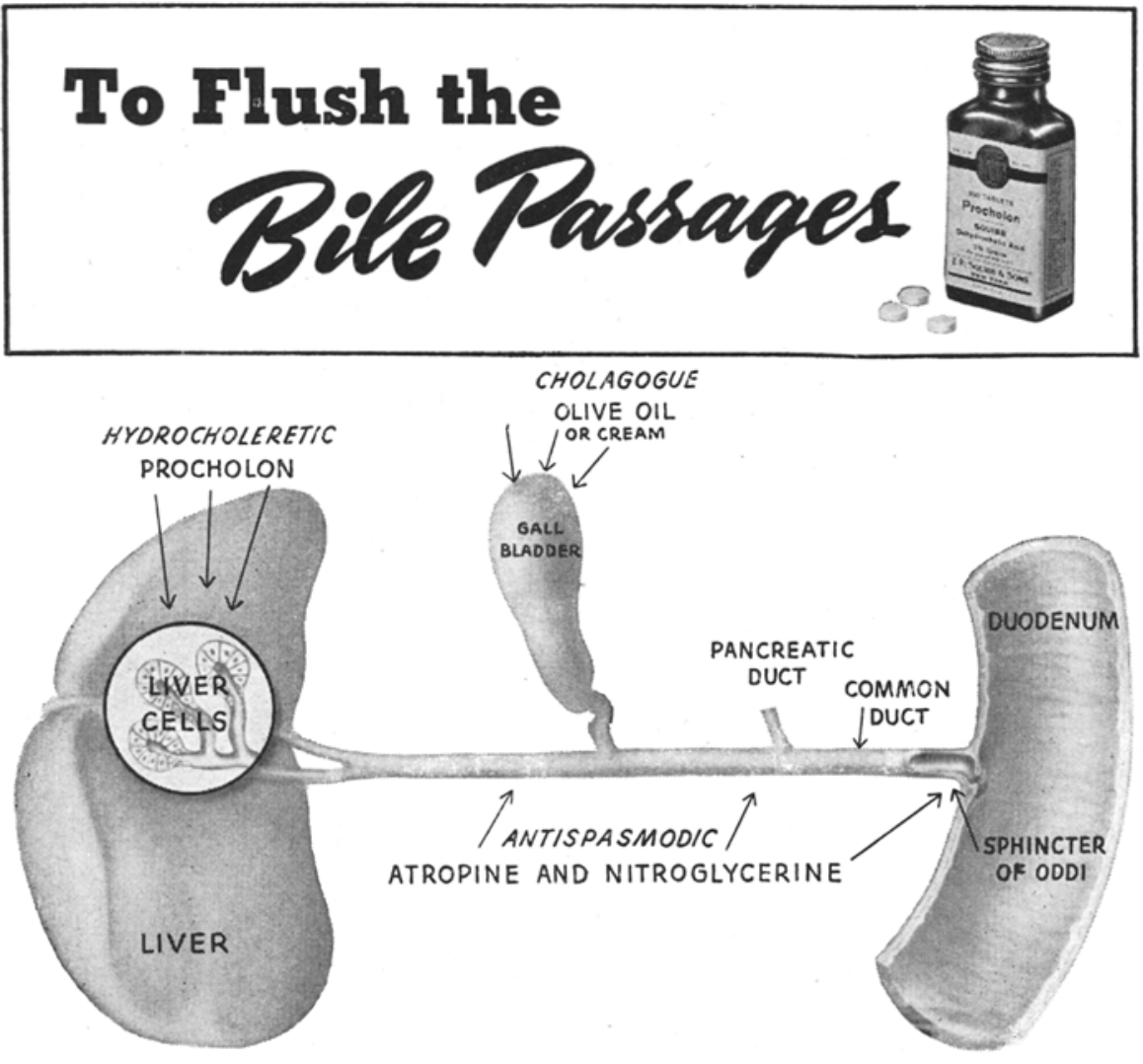

IN BILIARY STASIS, whether associated with inflammation of the gall bladder or biliary ducts, or with liver insufficiency, the problem of securing free flow of bile can be met by utilizing the hydrocholeretic activity of unconjugated dehydrocholic acid Procholon.*

Procholon is highly efficient in promoting the flow of low-viscosity bile. ${ }^{1}$ The drainage of the biliary ducts is encouraged, plugs of mucus and debris are swept onward. This mechanical action helps to check ascending infection of the biliary tract. Improvement in liver function has been observed $^{2}$ following administration of dehydrocholic acid.
Procholon is available for oral administration as $3 \frac{3}{4}$ grain $(0.25 \mathrm{Gm}$.); tablets in bottles of 25,100 , and 500 .

${ }^{1}$ Goldman, L., and Bell, H. G.: J. A. M. A. $17: 582$, Nov. 8, 1941.

2 Grodins, F. S.; Osborne, S. L.; Ivy, A. C., and Goldman, L.: Am. J. Physiol. 132:375, March 1941.

*"Procholon" (Reg. U. S. Pat. Off.) is a trademark of E. R. Squibb \& Sons.

For literature address the Professional Service Department, 745 Fifth Avenue, New York 22, N. Y.

\section{E.RSQUIBB \& SONS}

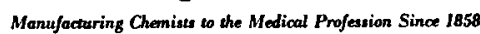

BUY AN EXTRA WAR BOND tomatoes, or salad greens, 45 ; dairy products, 34 ; leafy and yellow vegetables, 25 ; other vegetables or fruit, 8 ; meat, fish or poultry, 12 ; whole grain or enriched products, 3. Distributed according to geographical sections, the percentages of persons who did not eat the protective foods are shown in Table 6.

In Tables 7 to 11 are summarized the results from recent surveys, showing the percentages of persons failing to receive the recommended dietary allowances and the extent to which their diets are deficient in the several essentials.

It should be stated that some experts hold that since the recommended dietary allowances presumably represent "opt.mum" nutrition with a margin of safety. perhaps many persons who do not have the margin of safety are in no way deficient. In brief they object to labeling diets as deficient which fail to meet recommended allowances. This viewpoint raises two questions: At what levels of their constituent nutrients are diets deficient? What are the meaning and validity of the distinction between minimum and optimum levels?

Several opinions may be cited in support and interpretation of optimum levels as criteria. According to one: "Food plays an important part in determining the internal environment. and differences in this environment, many of which may be too small to be measured by present methods, definitely affect the plane on which physical and mental functioning go on. As far as the immediate or long-term wellbeing of a person can be improved through dietary betterment, that person falls short of being truly well fed." (37).

Another states: (38) "There is no reason to doubt, and good reason to believe, that the very wide margin of beneficial increase over absolute minimal need is as valid for human beings as for the experimental animals." Still another writes: (39) "If more were known about the actual vitamin requirements there would be no difference between minimum and optimal requirements, because the optimal presumably is the value which will per,mit no known pathology to develop 
TABLE 8

Percentages of Personis With Intake of the Respective Dietary Essentials At Less Than Recommended Levels

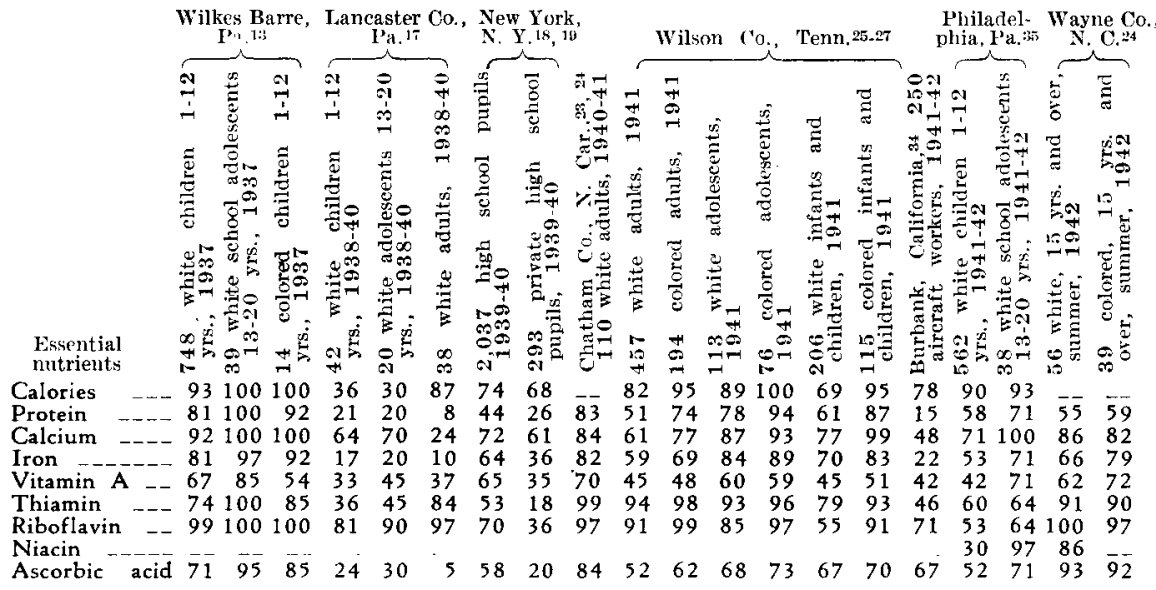

\section{F I I Jurenience a vid}

\section{FLEXIIB ILITY D F ID D SAGE}

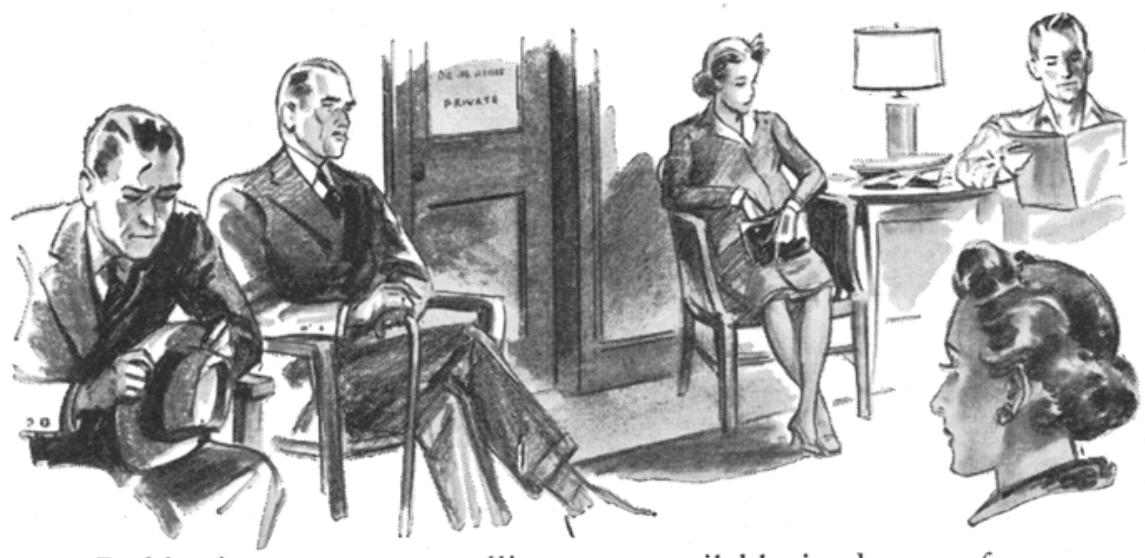

Bethiamin presents crystalline thiamine hydrochloride in three forms and in a range of dosages adequate for every need. For oral administration palatable Bethiamin Elixir provides $6 \mathrm{mg}$. of thiamine hydrochloride per ounce, and Bethiamin Capsules

are available in dosages from $1 \mathrm{mg}$. to $15 \mathrm{mg}$. For parenteral administration Bethiamin ampuls are available up to $100 \mathrm{mg}$. per cc. Thus Bethiamin places at the physician's hands dependable vitamin $B_{1}$ medication in the most convenient form.
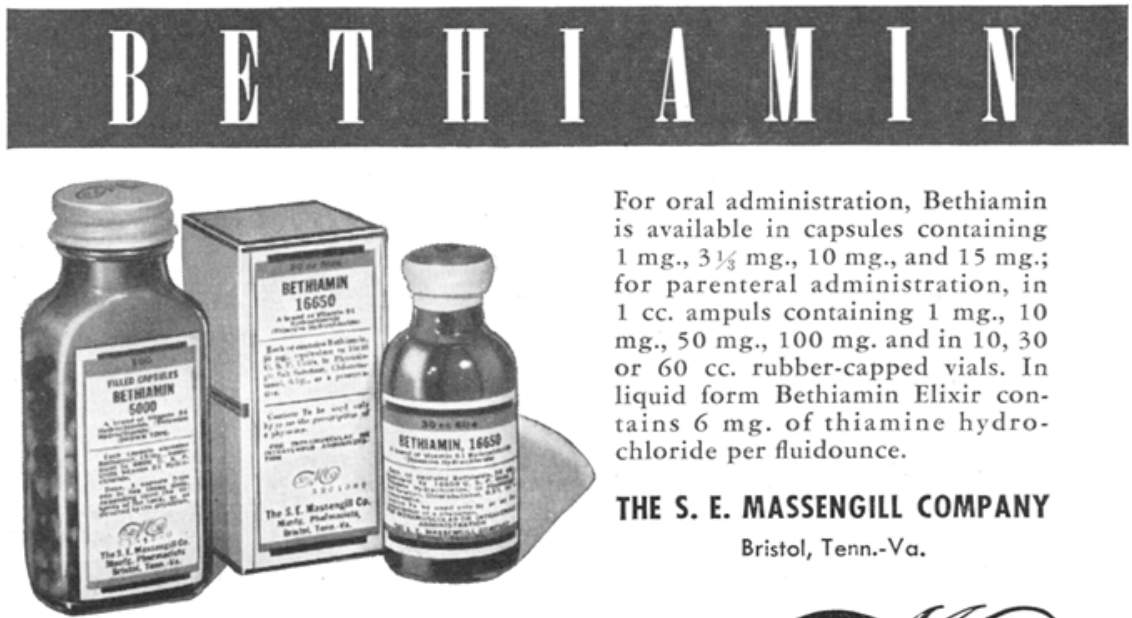

For oral administration, Bethiamin is available in capsules containing $1 \mathrm{mg} ., 31 / 3 \mathrm{mg}$., $10 \mathrm{mg}$., and $15 \mathrm{mg}$.; for parenteral administration, in $1 \mathrm{cc}$. ampuls containing $1 \mathrm{mg} ., 10$ mg., $50 \mathrm{mg}$., $100 \mathrm{mg}$. and in 10,30 or $60 \mathrm{cc}$. rubber-capped vials. In liquid form Bethiamin Elixir contains $6 \mathrm{mg}$. of thiamine hydrochloride per fluidounce.

THE S. E. MASSENGILL COMPANY Bristol, Tenn.-Va. and which will maintain the stores of the body at a maximum. Anything less than that could be considered insufficient."

I'ublications of the past two years confirm the view that the recommended allowances of the National Research Council provicle ample margins above the actual needs of normal people for energy, protein, and iron. But for the other nutrients, the levels are none too high or not high enough, according to the intimations in the latest review of the subject (40).

Nevertheless, Tables 8 to 11 present the proportions of families whose diets fail to meet not only the full recommended levels for constituent nutrients but also 75, 50, and 25 percent of these levels. From this scale anyone can take his choice of levels as a standard. The percentages of diets failing to meet the lower levels are slightly less than those falling short of the full allowances, but they are still very considerable.

\section{Deficiency States: Their Causes, Forms, and Detection}

All these surveys, without exception, revealed similar results: marked prevalence of dietary inadequacies as juclged by recommended standards. The evidence is consistent. From all the reports it is evident that very many persons are not receiving the recommended amounts of dietary essentials. Accordingly, the evidence that such a large proportion of the poptulation is eating unsatisfactory diets points to possible widespread prevalence of deficiency states. Indeed, inasmuch as diet surveys have limitations and other factors besides diet enter into the production of deficiency diseases, it is possible, if not probable, that deficiency states are more prevalent than indicated by results of dietary surveys.

Even when the diet seems to contain sufficient anounts of esientials. its adequacy is often apparent rather than real. Its adequacy is 1sually estimated from calculaterl values. It is well known that heat markedly destroys vitamin $C$, and it has recently been demonstrated that light causes destruction of riboflavin in food. Accordingly, analysis of pre- 
TABIE 9

Percentages of Persons With Intake of the Respective Dictary Essentials At Less Than 75 Percent of Recommended Levels

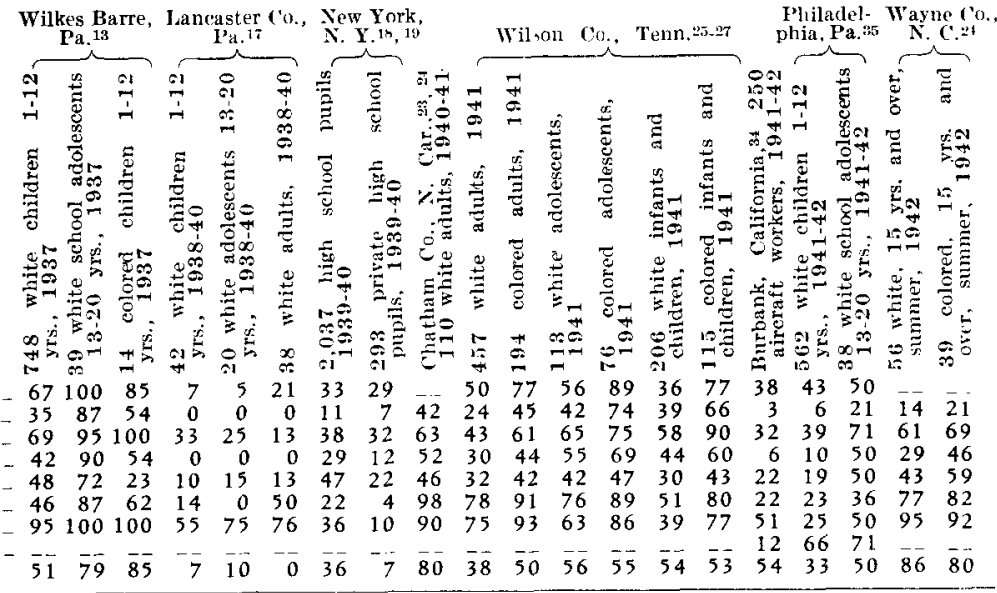
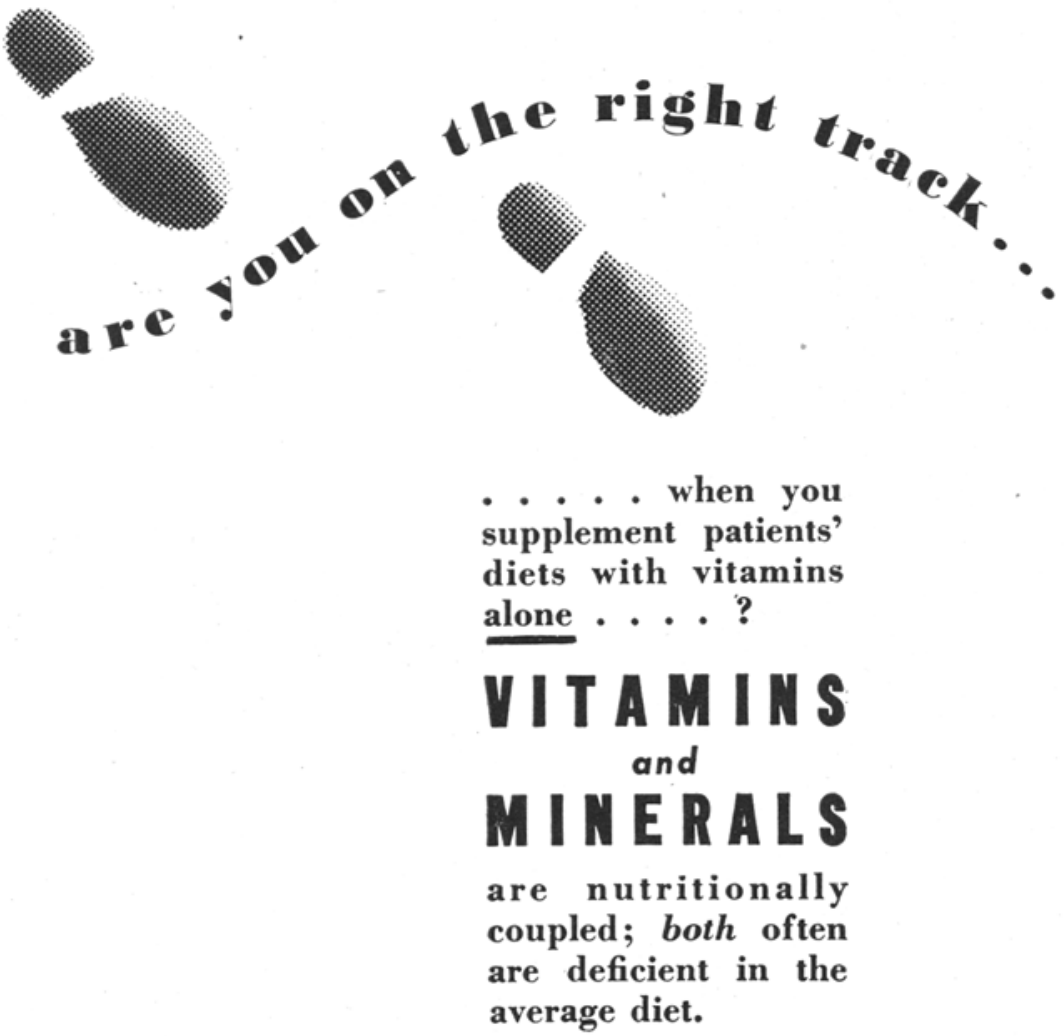

That is why more and more doctors are turning to

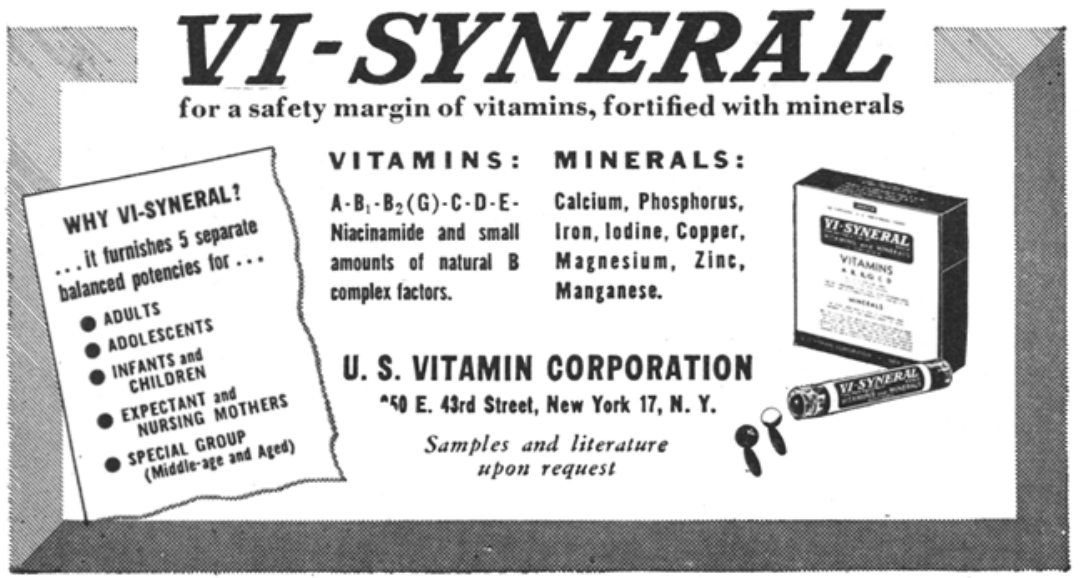

pared food shows mucil less than the estimated amounts of these essentials. Usually in est mates of cliets allowance is made for loss of vitanin $C$ by heat, but the deduction is often too small. No allowance is made for the destruction of riboflavin by light. Hence, diets adequate by calculation may really be deficient.

Furthermore, surveys at any time will show only dietary deficiencies at that period. It is probable that many persons having a good diet during the survey previously had a poor diet. Few persons have had a good diet throughout life. Unless a perfect diet has been eaten regularly, deficiency states will not have been prevented and nutrition will not be perfect. Slight deficiences are apt to be ignored as if they were without effect. Nor must the diet have been unsatisfactory over the entire past to lead to this undesirable state; it may have been poor for a short time or at intermittent periods. Persons who proully assert that their diet is exemplary seem to overlook their past record until prompting reminds them that their diet has leeen satisfactory only for the last few years, that it was unsatisfactory for a longer or shorter period in the past. They are apt to live in a false sense of security in the belief that the change to a satisfactory diet immediately and automatically expunged the consequences of their past unfavorable record. Kruse has pointed out that time and degree of deficiency are important in the evolution of cleficiency states. (41) Deficiencies occurring periodically or persisting over years produce cumulative effects. Slight deficiencies lead to cumlulative effects just as truly as marked defic:encies. Partially, inrleed slightly, deficient diets eaten regularly and periodically over many years have their consequences. Such conditions are very common. For these reasons, deficiency states are more prevalent and severe than indicated by dietary survey.

Even when diet actually contains the recommended amounts of essentials for basal needs and the body is functionally sound, deficiency states may still occur. The standards of dietary essentials are average and 
TABLE 10

Percentages of Persons With Intake of the Respective Dietary Essentials At Less Than 50 Percent of Recommended Levels

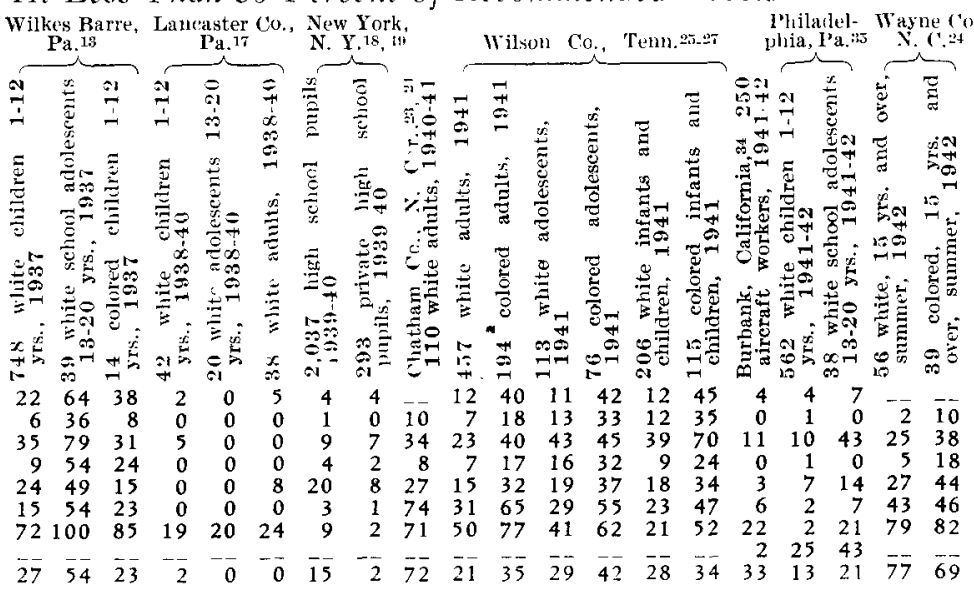

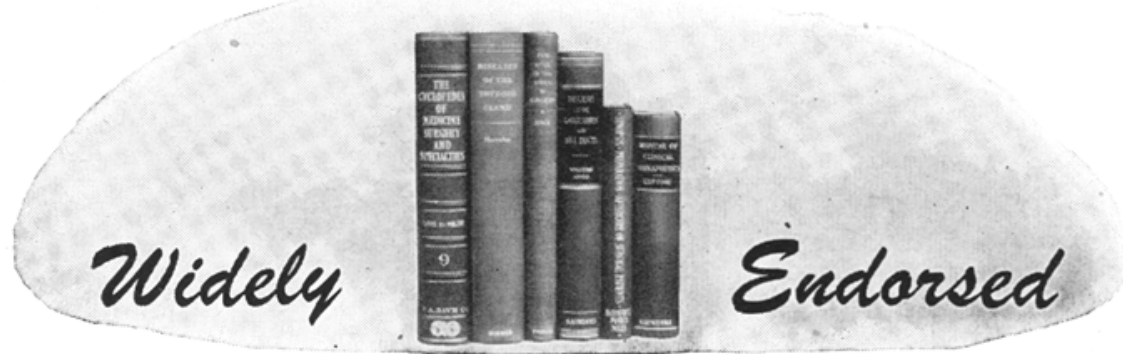

\section{as a Valuable Aid Before and After BILIARY TRACT SURGERY}

Its potent hydrocholeretic action has made Decholin (theoriginal dehydrocholic acid) a widely accepted addition to the surgeon'sarmamentarium.

Administered preoperatively, Decholin (oral) or Decholin sodium (intravenous) produces a copious outpouring of thin, free-flowingliverbile, secreted under increased pressure, which causes the bile ducts and gallbladder to stand out prominently, facilitating identification and manipulation during surgery.

After cholecystectomy, when external drainage has not been instituted, Decholin tablets may be given as soon as tolerated, usually after 48 to 72 hours. The induced hydrocholeresis improves drainage of the common duct, aids in the removal of debris, reduces postoperative discomfort. If complete blockage due to a stone or tumor mass existed before surgery, Decholin hastens the resumption of bile secretion.

When the common duct is drained to the outside, Decholin assures free drainage, aiding in the removal of clots, inspissated bile, and small stones overlooked at surgery.

Decholin is contraindicated only in complete obstruction of the common or hepatic bile duct. Supplied in boxes of $25,100,500$ and 1000 tablets.

Physicians are invited to send for a copy of the 4th (condensed) edition of the brochure "Biliary Tract Disturbances"

Riedel - de Haen Inc. - New York 13, N. Y.

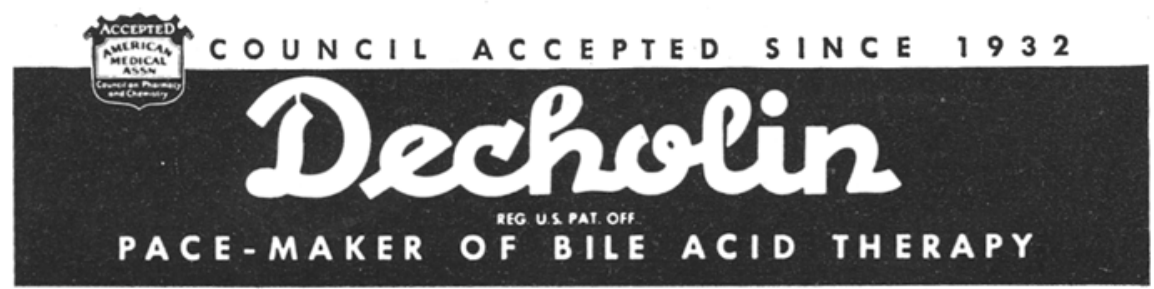

make no allowance for individual differences and all increased needs. In a review of this topic Jolliffe (42) has pointed out that certain conditions known as conditioning factors raise the requirements for essentials above the basal level. First, sex and age are indices of increased need: the former because of pregnancy and lactation; the latter because of growth. Secondly, physical exertion raises requirements for essentials. When per sons with acute pellagra are kept in bed, even though they be given a pellagra-producing diet, their pellagra temporarily disappears. Thirdly, exposure to light has been reported as increasing the need for certain essentials, particularly riboflavin, nicotinic acid, and vitamin $\mathrm{A}$. Fourthly, exposure to toxic substances increases bodily needs for essentials. Alone, any one or all of these several factors do not produce deficiency states but they may exert a determining or occasioning influence.

In setting dietary allowances, the influence of age, sex, pregnancy, lactation, and physical activity is recognized. It is evident that dietary requirements are not constant, fixed, absolute values but are relative to the conditioning factors that increase bodily needs. Often these factors act in combination. Hence, deficiency states may occur on a seemingly adequate diet. Thus, as$\mathrm{suming}$ a satisfactory internal mechanism, a deficiency disease may arise from an insufficient intake relative to age, activity, and exposure to light, as well as to other forms of trauma. Of course, if a deficiency state is already present. lowered storage and impaired tissue condition also raise the requirements.

Still other conclitioning factors raise bodily requirements for essentials creating a deficiency. For the most part they are diseases, including infections, and therapeutic agents. Differentiation of these conditioning factors from the preceding group is largely artificial. For one thing, they are not regarded as natural events in the sense that disease is not apt to be accepted as a necessary or normal occurrence. Besides, they are apt to raise the tissue 
TABLE 11

Percentages of Persons With Intake of the Respective Dietary Essentials At Less Than 25 Percent of Recommended Levels

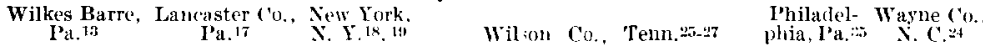

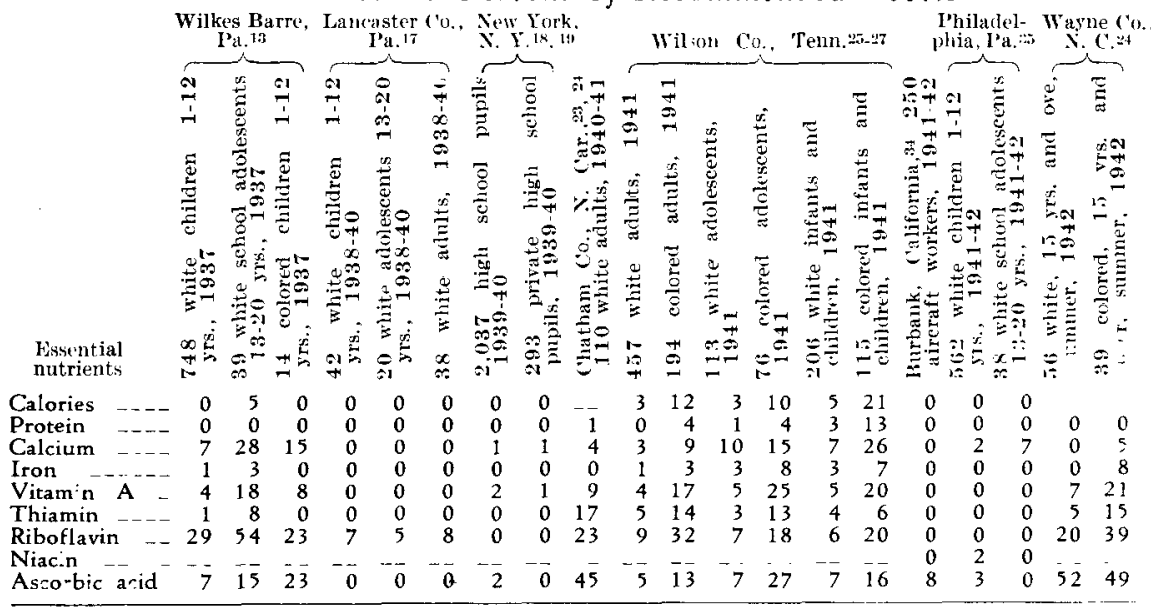

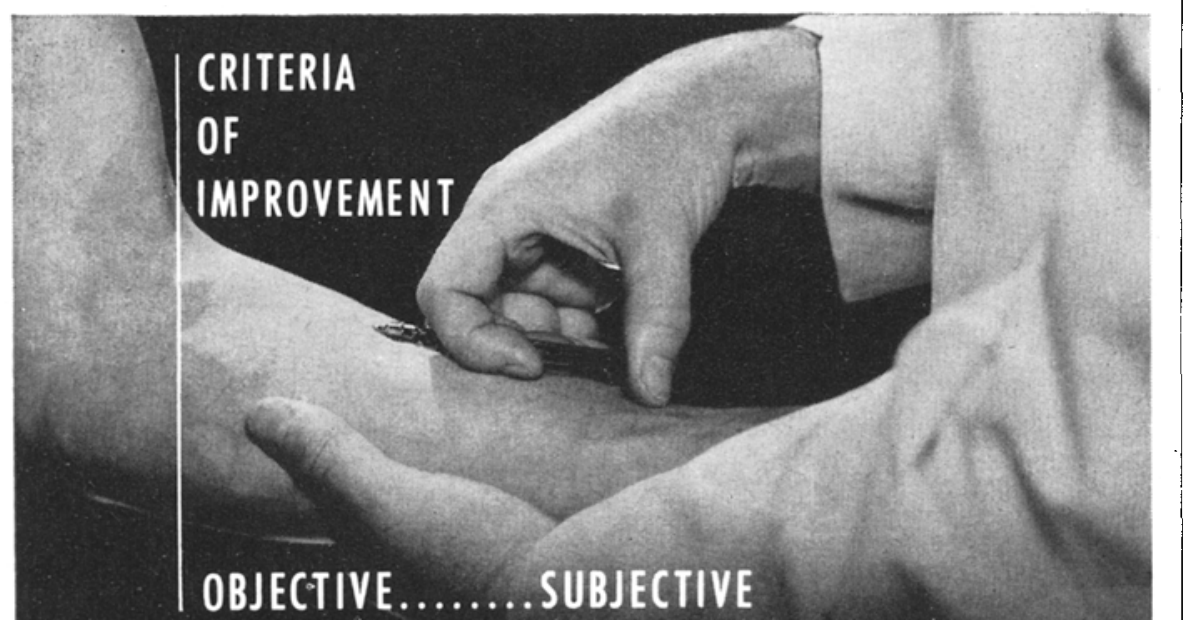

IN TREATING the irritable colon, $\mathbf{I}_{\text {Soricin aids in overcoming }}$ the ill effects of toxic absorption by detoxifying bacterial products in the bowel without altering their antigenic value. The improvement noted following the use of Soricin is not only subjective, but there is also a marked diminution of the patient's sensitivity to bacteria as evidenced by skin test reactions.

In an investigation*, 1 minim of a suspension of individual strains from each patient's stool was injected intradermally prior to treatment and the reaction observed.

After a course of therapy with Soricin (5 to 30 grs. 4 times daily, before meals and at bed-

time) skin sensitivity to intestinal organisms was reduced materially in $90 \%$ of the cases. The author concludes that these objective findings confirm the definite beneficial effect of Soricin in irritable colon.

\section{SORICIN}

Brand of Sodium Ricinoleate Soricin Tablets, Soricin with Bile Salts Tablets, and Soricin with Bile Salts and Pancreatin Tablets are available at prescription pharmacies in bottles of 100 and 1000 .

Write for Sample and Literature

"Burger, G. N.: The treatment of irritable colon with sodium ricinoleate, J. Lab. \& Clin. Med. 19:234-243 (1933).

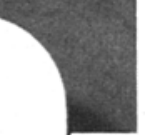

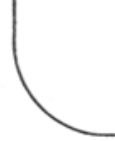

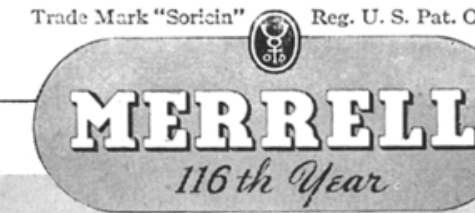


cover actual existing conditions. In speaking of deficiency diseases. physicians have been thinking of the severe acute form. Nearly all animal experimentation has aimed at production of this form. Almost all medical literature bears only on the severe acute form. Until recently none other was recognized. But actually there is relatively little of the severe acute form in this country.

Recently, however, Kruse has demonstrated that there is widespread prevalence of deficiency diseases, not in the traditionally severe acute state but in other forms. (41)
He has found that they are very prevalent in a chronic form. Following is a stummary of his views based tupon gross and biomicroscopic examination. In biological behavion the chronic differs from the acute; whereas the acute is rapicl, the chronic is slow in development and in response to treatment. Furthermore, both the acute and chronic processes may be of any intensity from mild to marked. Chronic processes of marked intensity are seen quite frequently in the population. In brief, deficiency diseases have been shown to be widespread

\section{SIMPLE, QUICK URINE-SUGAR TESTING WITH}

\section{CLINITEST \\ (A Tablet Copper Reduction Method)}
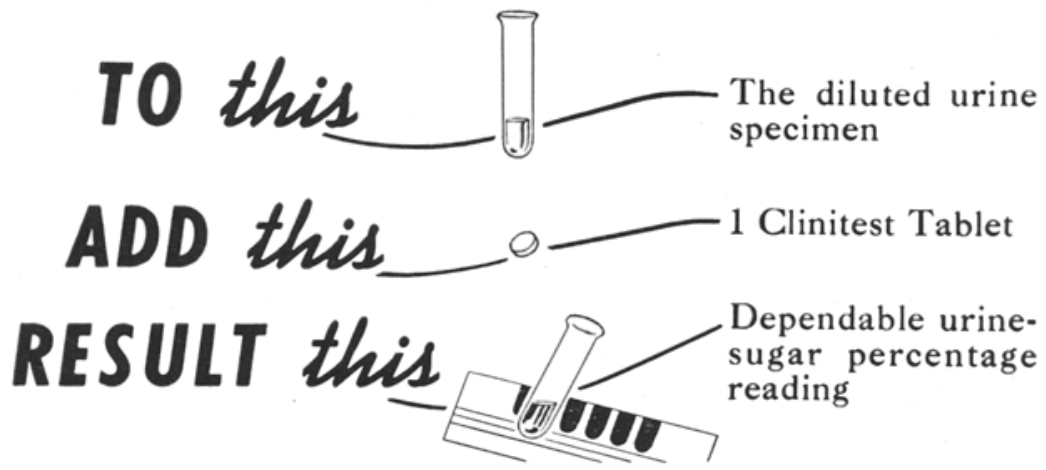

No Fussing • No Measuring • No Complicated Technic

No Boiling • No Flame • No Powders to Spill

Clinitest is ideal for routine regulation of diet and insulin.

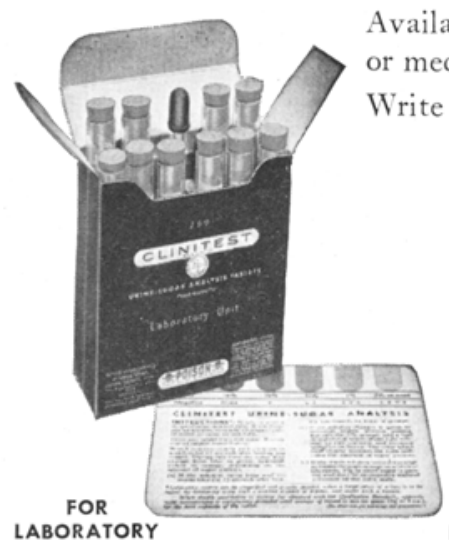

Available through your prescription pharmacy

medical supply house.

rite for full descriptive literature. Dept. D.D.5

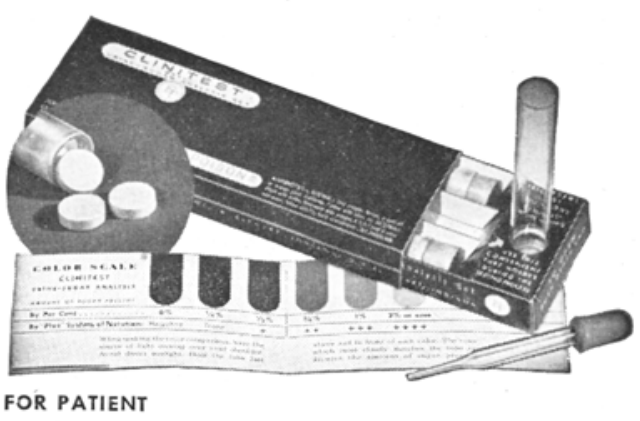

EFFERVESCENT PRODUCTS, INC. ELKHART, INDIANA in previously unrecognized forms: mild acute, mild chronic, and severe chronic. The acute and chronic processes may be present together. Indeed, not infrequently an acute is superimposed on a chronic condition. Each may be in a different stage and of a different intensity. It should be emphasized that this refers to each kind of deficiency disease. Characteristic tissue changes reflecting form, legree, and stage have been demonstrated in each of four deficiency states. So common, so prevalent, so frequently seen are some of these changes, especially their slighter clegrees, that they have been regarded as usual or normal. But their specific location, distinctive and characteristic nature. their reversibility, all attest to their pathological identity as deficiency states.

Time is a factor in the evolution of both the acute and chronic forms; but it is particularly important in the development of the chronic process. In man's life, time is measured by age. Accordingly, the prevalence and severity of the chronic processes increase with age. Most of the chronic changes have hitherrto been regarded mistakenly as characteristics of senescence. In reality, however, they are deficiencies developing slowly over a lifetime. These chronic processes may be seen beginning in childhood, even in infancy. The lower the economic level, the more frequently, the more severe, and the earlier in life they occur.

A person's nutritional status today depends on the events of all past days. Upon reflection it is clear that few people have had a satisfactory intake or escaped adverse conditioning factors every day of their lives. These lapses are reflecterl in tissue changes and, until recently, attempts were seldom made to correct them entirely. Indecd, many persons continue on an inadeculuate diet for years. Hence, the tissues show the cumulative changes of long, slowly cleveloping chronic as well as rapiclly progressing acute processes. All points considered, Kruse conclucles, it is to be expected that the prevalence of deficiency states is high. 


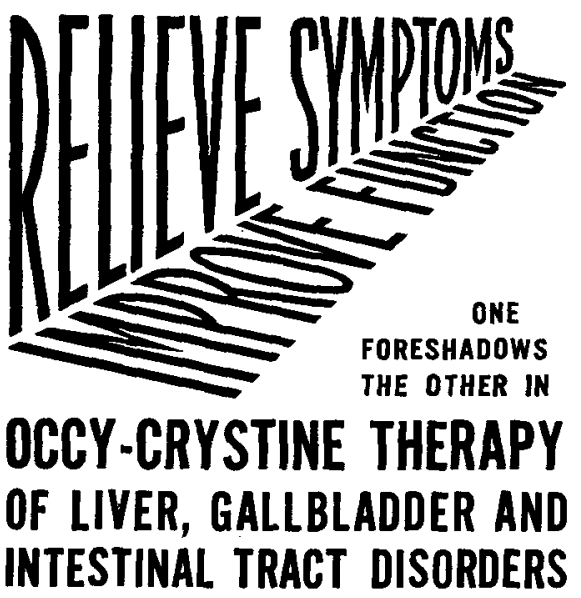

N THE gastroenterologic division of one of America's leading medical schools and hospitals, fourteen separate tests of liver and gallbladder functions and of the detoxifying effect of Occy-Crystine have strikingly demonstrated the value of this agent in improving blood, bile and urine chemistries - and, concomitantly, in alleviating presenting symptoms and increasing the patients' sense of well-being.

Occy-Crystine's action is (1) cholagogic, (2) cathartic, (3) diuretic, and (4) sulfur-bearingwhich makes it particulary valuable for the relief of many cases of such conditions as catarrhal jaundice, hepatitis, chronic hepatic dysfunction, chronic portal cirrhosis, chronic passive congestion of the liver, chronic or calculous cholecystitis, biliary dyskinesia, obstructive cholangeitis, chronic biliary cirrhosis, post cholecystectomy - as well as in atony of the colon, giardiasis, spastic and atonic constipation, hepatointestinal toxemia, etc.

FORMULA: Occy-Crystine is a hypertonic solution of $\mathrm{pH} 8.4$, made up of the following active ingredients-sodium thiosulfate and magnesium sulfate, to which the sulfates of potassium and calcium are added in small amounts, contributing to the maintenance of solubility.

OCCY-CRYSTINE LABORATORY SALISBURY, CONN.

\section{DCCY-DVYSTINA}

-the specialized

saline detoxicant-eliminant

OCCY-CRYSTINE LABORATORY, Salisbury, Conn.

Please send samples and clinical report. A/D-5

Dr.

Address
REFERENCES

1. W'ehI, Dorothy G.: Diets of Low-Income Fami ies in New York City. Quarterly Bullet.n of the Milbank Memorial
Fund, 11:308.324 (No. 4, Oct.) 1933 .

2. Wiehl, Dorothy G.: Diets of Low-Income Families Surveyed in 1933. Health and Depression Studies No. 3. Public Health Reports, 51:77.97 (No. 4, Jan. 24),
1936.

3. Wieh1, Dorothy G.: Diets of Urban Fam lies with Low Incomes. An Analysis of Weekly Food Budgets in 472 Families in Baltimore, Cleveland, Detroit, Pitts-
burgh, and Syracuse in April-May 1933. burgh, and Syracuse in April-May 1933. Milbank Memorial Fund Quart.

4. Stiebeling, Hazel K. and Phipard, Esther $F_{*}:$ Diets of Families of Employed Wage Earners and Clerical Workers in Cities. U. S. Department of AgriculJan. 1939.

5. St ebeling, Hazel K.; Monroe, Day; Coons, Callie M.; Phipard, Esther F.; and Clark, Faith: Famity Food Consumption and D'etary Leve's, Five Pegions. Consumer Purchases Study,
Farm Series. U. S. Department of Arriculture, Misc. Publication No. 405. Washington, 1941 .

6. Stiebeling, Hazel K.; Monroe, Day; Ph pard, Esther F; Adelson, Sayde F.; and Clark, Faith: Family Food Con sumption and Dietary Levels, Five Re.
gions. Consumer Purchases Study, Urgions. Consumer Purchases Study, Ur ban and Village Series. U. S. Departmo. 452, Washington, 1941

7. Recommended Dietzry Allowances. National Research Council, Reprint and Circular Series No. 115, Washington, D. C., Jan. 1943.

8. Food and Drugs. Federal Register, 6: 5922,5925 (No. 227, Nov. 22), 1941, Title 21 .

9. Stiebeling, Hazel $K$, and associates: Un. published data.

10. Stiebe'ing, Hazel K.: Food Consumption Studies and Dietary Recommendations.
Federation Proceedings, 1: $327-330$ (No. 3, Sept.), 1942.

11. Britton, Virginia: Food Consumption of 538 Fartm and 299 Village Families in Vermont. Vermont Agricultural Ex. periment Station, Bulletin No. 474. Burlington, Vt., June 1941 .

12. Sanders, Agnes P. and Mack, Pauline B. Unpublished data.

13. Mack, Pauline B. and associates: Unpub. lished data.

14. Wiehl, Dorothy G. and Palmer, C. E.: Summer Diets of the Poor in Wash. ington, D. C. Mifbank and Mernor a!
Fund Quarterly, 17:5-28 (No. 1, Jan.), Fund

15. Murphy, Elizabeth: A Study of Vitamin C Nutrition in a Group of School Children. II. Dietary Evaluation. Journal of Nutrition, 21:527.539 (No. 5, May 10), 1941 .

16. Reynolds, May S.; Ohlson, Margaret A.; Pittman, Martha S.; McKay, Hughina; Patton, Mary Brown; Donelson, Eva: Leverton. Ruth: Meiller, E'la J:: and Bitting. Mary H.: The Detary Habits of College Students. Journal of Home Economics, 34:379.384 (No. 6, June), 1942.

17. Smith, Janice $M$ and associates: Unpublished data.

18. Wieh1, Dorothy G.: Medical Evaluation of Nutritiona! Status. VII. Diets of High School Students of Low Income Fami'ies in New York City. Mlbank Memorial Fund Quarterly, 20:61-82
(No.1.Jan.) 1942.

19. Wiehl, Dorothy G.: Unpublished data.

20. Gr'gsby, Nora E.; McBryde, Laureame C.; and Davis, H. J.: A Study of the Adequacy of Diets of Farm Security Ad ministration Families in Lou siana. Nu. trition Laboratories, College of Agricu'. ture, Louis'ana State University, Ba. ton Rouge, Louisiana. Mimeographed
Leaflet, Sept. 15, 1942.

21. Kelly, H. T. and Sheppard, Myrtle: A Dietary Study of Subjects from UppeIncome Groups. New England Journa 1943 .
22. Hardy Martha C.: Spohn, Adelaide; Austin, Gertrude; McGiffert, Sarah; Moht, Edna; and Peterson, Agnes B.: Nutritional and Detary Inadequacies Among City Children from Different SocioEconomic Groups. Journal of the 181 (No. 3, March), 1943.

23. Milam, D. F:: A Nutrition Survey of a Small North Carolina Community. Am. erican Journal of Public Health, 32: 406.412 (April), 1942 .

24. Milam, D. F.: Unpublished data.

25. Youmans, John B.: Patton, E. White; and Kern, Ruth: Surveys of the Nu trition of Populations. American Jour nal of Public Health, 32:1371-1379 (No. 12, Dec.), 1942 .

26. Youmans, John B.: Patton, E. White; and Kern, Ruth: Surveys of the Nunal of Public Health 33:58-72 (No. 1, Jan.), 1943.

27. Youmans, John B.; Patton, E. White; Kern, Ruth; Sutton, W. R.; and Stein kamp, Ruth: Unpublished data.

28. Clayton, Mary M.: A Study of the Food Habits and Nutritional Status of Children in Selected Communities in Maine. The Maine Agr cultural Experiment Station Bulletin No. 405,

29. Clayton, Mary M.: The Nutritional Status of University of Maine Freshman Girls of University of Maine Freshman Girls
as Related to Their Diets. Maine Agri. as Related to Their Diets. Maine Agri. 405, pp. 437-438, Orono, Me,, June

30. Willard, W. R.: Working for Better Nu trtion in a Rural Community, Amer can Journal of Public Health, 32:996. 1000 (Sept.), 1942 .

31. Bryson, Bertha E.; Tucker, Clara; and Davis, H. J.: A Study of the Diets of Home Demonstration Club Members' Families in Twenty-Seven Parishes of Louisiana. Louisiana Bulletin No. 356 , Louisiana State University Agricultural Exper:ment Station, Baton Rouge, La. Dec. 1942.

32. Coco, Lucille D.; Moore, Margaret; Gold smith, Grace A.: Lucas. G. P.; and Davis, H. J.: A Study of the Adequacy of Diets Consumed by Grade-School and High-School Students in Louisiana. Louisiana Bulletin No. 360 , Louisiana State Universitv Agricultural Experiment Station, Baton Rouge, La., Jan. 1943 .

33. Downes, Jean: A Study of Food Habits of Tuberculous Families in a Harlem Area of New York City. Milbank Me. morial Fund Quarterly, 21:164-181 (No. 2, April), 1943

34. Wiehl, Dorothy G.: Diets of a Group of Aircraft Workers in Southern California, Milbank Memorial Fund Quarter-
ly, 20:329-336 (No. 4, Oct.) 1942.

35. Mack, Pauline B.; Urbach, Char'es; Smith, Janice M.; Logan, Cather ne H.; Rose, Elizabeth K.; Stewart, A. H.; and Dodds, Paul: A Contribution to the Study of Nutritional Status in Rural State College Bulletion, 36: (No. 52). 1942.

36. Gallup, George: Report from American Institute of Public Opinion. New York Timstiture of Public Op

37. Stiebeling, Hazel K.: Adequacy of Amer can Dints. Journal of the American Medical Association, 121:831.838 (No. 11, March 13), 1943

38. Sherman, H. C.: Chemistry of Food and Nutrition. S xth Edition. New York,

39. Bing, F. C.: Foods as soutces of the Vitamins. Federation Proceedings, 1:296303 (No. 3, Sept.), 1942.

40. Lanford, Caroline S. and Sherman, H. C. Nutrition, 1941 and 1942. Annual $R e$ view of Biochemistry, 12:397.424, Stan-
ford University, California, 1943 .

41. Kruse. H. D.: A Concept of the Deficiency States. Mitbank Memorial July), 1942 .

42. Jolliffe, Norman: Conditioned Malnutrition. Journal of the American Medical Associat on, 122:299.306 (No. 5, May 29), 1943 .

(To Be Contimued) 